REVISTA DE DERECHO UNED, NÚM. 24, 2019

\title{
ELEMENTOS DE LA PRESCRIPCIÓN DE LA INFRACCIÓN TRIBUTARIA
}

\section{TAX INFRINGEMENT PRESCRIPTION ELEMENTS}

\section{IVÁN PÉREZ JORDÁ}

Funcionario de Administración Local con habilitación de carácter nacional. Doctor en Derecho Financiero y Tributario. Profesor Asociado de Derecho Administrativo en la Universidad de Valencia.

Licenciado en Ciencias Políticas. Doctorando en Filosofía y Letras en la UNED

Resumen: El presente artículo se analiza detenidamente la prescripción de la responsabilidad dimanante de la infracción tributaria así como algunos de los requisitos necesarios para la prescripción de la responsabilidad infractora, en concreto, la consumación del hecho tipificado como infracción, la inacción administrativa y, de modo general y no pormenorizado, el transcurso del plazo previsto normativamente. ción.

Palabras clave: Prescripción, infracción tributaria, consuma-

Abstract: This paper analyses thoroughly the tax infringement prescription as well as some of the necessary requirements for the responsibility offender prescription, in concrete, the consummation of the infringement fact, the administrative inaction and, in general, when the statutory waiting period expired.

Keywords: Limitation period, tax infringement, consummation.

Recepción original: 17/07/2018

Aceptación original: 01/02/2019 
Sumario: I. Concepto, fundamento y naturaleza de la prescripción de la infracción tributaria. I.1. Concepto de la prescripción extintiva de la infracción tributaria. I.2. Fundamento de la prescripción extintiva de la infracción tributaria. I.3. Naturaleza de la prescripción extintiva de la infracción tributaria. II. El objeto de la prescripción sancionadora en materia tributaria. III. Requisitos de la prescripción de la infracción tributaria. III.1. Consumación de la infracción. III.2. Inactividad del titular del derecho sancionador tributario. III.3. Transcurso del plazo. III.3.1. Día inicial del cómputo del plazo prescriptivo. III.3.2. Día final del cómputo del plazo prescriptivo. IV. Conclusiones.

\section{CONCEPTO, FUNDAMENTO ${ }^{1}$ Y NATURALEZA DE LA PRESCRIPCIÓN DE LA INFRACCIÓN TRIBUTARIA}

\section{I.1. Concepto de la prescripción extintiva de la infracción tributaria}

La prescripción y la caducidad surgieron históricamente en el Derecho Civil, sin embargo, posteriormente, se han utilizado estas formas jurídicas en otras ramas del Derecho al servicio de fines distintos ${ }^{2}$. En el Derecho tributario, la prescripción, a diferencia del Derecho Civil, sí es una forma - entre otras- de extinción, de la obligación tributaria ${ }^{3}$, de la responsabilidad derivada de la infracción y de la sanción tributaria.

Nos ilustra Martín Cáceres ${ }^{4}$ que el análisis histórico de la prescripción en el ordenamiento tributario permite constatar la existencia de dos fases delimitadas entre sí por la promulgación de la Ley 230/1963, de 28 de diciembre, General Tributaria (LGT 1963). Con

${ }^{1}$ Preliminarmente, se puede afirmar que la caducidad, unida a la prescripción, tiene un efecto limitativo sobre los efectos de la interrupción de esta última figura, de tal forma que se trata de no eternizar la resolución de los procedimientos administrativos relativos a un contribuyente en relación con un determinado concepto impositivo y período de liquidación. ALONSO ARCE,I.: «La caducidad como límite a las interrupciones de la prescripción», JT, núm. 9,2005,pág. 2.

2 Así FALCÓN Y TELLA,R.: La prescripción en materia tributaria, La Ley,Madrid,1992, págs. 47 y 48.

3 RUÍZ RESCALVO,M.P.: La prescripción tributaria y el delito fiscal, DykinsonUniv. Rey Juan Carlos I,Madrid, 2004, pág. 29.

${ }^{4}$ En efecto, frente a los ordenamientos jurídicos referenciados, la LGT 1963 reviste carácter especial respecto de las normas reguladoras de la prescripción extintiva del Código Civil, siendo por tanto de aplicación preferente...todo ello sin perjuicio del valor supletorio del Derecho Común....MARTÍN CÁCERES,A.F.: La prescripción del crédito tributario, Marcial Pons,Madrid,1994, págs. 13-14. 
anterioridad a la citada Ley, la regulación del instituto prescriptivo se caracterizaba por la dispersión normativa y la variedad de los plazos en cuanto a su duración. Efectivamente, excepto en lo relacionado con la Ley de Administración y Contabilidad de la Hacienda Pública de 1911, cuyo artículo 29 era aplicable a la generalidad de los tributos, el instituto prescriptivo era objeto de regulación específica en la normativa propia de cada tributo. Además, la falta de precisión en la calificación de los plazos como de caducidad o prescripción, determinó una legislación sobre la prescripción verdaderamente intrincada en la que la única constante parecía ser la distinción entre el plazo de prescripción y el de caducidad. Esta situación cambió tras la promulgación de la LGT 1963, cuyos artículos 64 a 66 confirieron al instituto prescriptivo un carácter específico, incluso en el contexto del Derecho comparado. En este sentido, la LGT 1963 se sitúa entre el Derecho Tributario italiano, que carece de una normativa aplicable de carácter general ${ }^{5}$, y la Ordenanza Tributaria Alemana de 1977, cuya regulación sobre la prescripción es exhaustiva.

Sin perjuicio de las múltiples definiciones existentes ${ }^{6}$, desde nuestro punto de vista podemos definir la prescripción de la infrac-

${ }^{5}$ FALCONE,G.: Aggiornamento XI Della Enciclopedia giuridica. Prescrizione III. Diritto Tributario, Fondata da Giovanni Treccani, S.p.a.,Roma, 2003, pág. 2002.

${ }^{6}$ La prescripción de la infracción tributaria, según LOZANO CUTANDA es una institución que resulta común a todo el ordenamiento jurídico y supone el reconocimiento de los efectos que ocasiona en el mundo del Derecho el transcurso del tiempo. LOZANO CUTANDA,B.: La extinción de las sanciones administrativas y tributaria, Marcial Pons,Madrid,1990,pág. 201; Se comprende así la importancia que presenta este instituto jurídico, para FUSTER es un principio - eso sí, no de carácter constitucional - . FUSTER ASENCIO,C.: El procedimiento sancionador tributario, Aranzadi, Navarra, 2001, pág. 118; Es en el ámbito punitivo, donde determina la invalidez, por el transcurso del tiempo del valor que han tenido determinadas conductas ilícitas. ANEIROS PEREIRA,J.: Las sanciones tributarias, Marcial Pons, Madrid, 2005, pág. 152; BLASCO DELGADO , que no realiza propiamente una definición, la ha conceptuado por sus caracteres como aquel instituto cuyo objeto es la extinción de la responsabilidad derivada de la comisión de un ilícito tributario, y que como consecuencia del paso del tiempo, imposibilita la posterior actuación de la Administración Tributaria en orden a sancionar. BLASCO DELGADO,C.: La prescripción de las infracciones y las sanciones, Civitas, Madrid, 2003, págs. 85 a 94; ESCRIBANO prefería no plantear la cuestión en términos alternativas, y así afirmaba que nos encontramos simplemente ante un instituto jurídico tributario que teniendo características heterogéneas, según los parámetros civilísticos, condiciona el ejercicio de facultades y derechos al paso del tiempo, sancionando la conducta negligente de la Administración o del administrado en razón del principio de la seguridad jurídica y certeza de las relaciones ordenadas por el derecho.[ Aunque se trataba de un artículo del año 1976, que relativizaba las diferentes entre plazos de prescripción y caducidad en materia de extinción de obligaciones tributarias. JUAN LOZANO,A.M.: La interrupción de la prescripción tributaria. Análisis de jurisprudencia y doctrina administrativa, Tecnos, Madrid,1993, pág. 15]; DE MIGUEL CANUTO

(C) UNED. Revista de Derecho UNED, núm. 24, 2019 
define la prescripción, como institución, se fundamenta en el que el tiempo hábil para que la Administración actúe su potestad, esto es, la concrete en acto, en este sentido tiene una significación procedimental. Por otra parte, el incumplimiento de esa regla temporal de prescripción alcanza una significación sustantiva, extinguiendo la responsabilidad del infractor. Son dos aspectos que no deben ser contrapuestos, y no pueden ser independizados el uno del otro. (A mayor abundamiento, este autor no comparte la diferenciación que efectúan LONGAS LAFUENTE y MORENO TOSCANO entre prescripción de la infracción (entendida como extinción de la responsabilidad por el ilícito) y la prescripción de la acción para imponer sanciones. DE MIGUEL CANUTO,E.: La prescripción de las infracciones y sanciones tributarias, Tirant lo Blanch,Valencia,2000,págs. 16 a 18; De hecho LONGAS LAFUENTE afirma que si...la potestad sancionadora es imprescriptible...deberemos concluir que lo único que puede prescribir es la responsabilidad derivada de la infracción tributaria. LONGAS LAFUENTE,A.: «El plazo de prescripción de las infracciones tributarias: estudio del artículo 64.c) de la L.G.T. Incidencia de la Ley 30/1992, de 26 de noviembre», $C T$,núm.80,1996, pág. 84; FALCÓN Y TELLA define la prescripción como un medio de extinción de la responsabilidad o de la sanción, considerando la imposibilidad de realizar un concepto unitario de prescripción tributaria, aunque, a diferencia de la caducidad, sólo pueden quedar sometidos a prescripción el derecho y acciones, frente a las facultades o las potestades administrativas, que por su propia naturaleza, sólo son susceptibles de caducidad. FALCÓN Y TELLA,R.: Análisis crítico de jurisprudencia en materia de prescripción de las infracciones y sanciones tributarias, IEF, Madrid, núm.76,1990, págs. 18 y 19; FALCON Y TELLA,R.: La prescripción ...op. cit.,pág. 51; GÉNOVA GALVÁN la definía como un plazo de caducidad que se proyecta sobre el ius puniendi, en la medida que se trata del ejercicio por parte de un ente público de una potestad, que, desde el punto de vista del concreto régimen positivo del instituto, ha de tomarse con todas las reservas. GÉNOVA GALVÁN,A.:«La prescripción tributaria», $R E D F$,Civitas,Madrid,núm.5 7,enero-marzo,1988; CALVO ORTEGA define la prescripción como figura extintiva de las infracciones tributarias, por el transcurso de un período de tiempo determinado y la falta de actividad administrativa, que produce el efecto extintivo. CALVO ORTEGA,R.: Curso de Derecho Financiero. Derecho Tributario. Parte General, Civitas, Madrid,2010, pág. 242; FERREIRO admite que la distinción entre prescripción y caducidad ha sido uno de los problemas de resolución más confusa que se ha planteado la teoría general de la extinción de las relaciones jurídicas, pues ambas figuras sirven a un mismo fin (la seguridad) a través de una técnica similar: la pérdida de una determinada utilidad como consecuencia del transcurso de un determinado lapso de tiempo. Y ello explica la falta de un acuerdo general en su deslinde entre la doctrina. Sin embargo, podemos decir que una gran parte de los autores que se han ocupado del tema podrían estar de acuerdo con referir la caducidad a un acto determinado de ejercicio de un derecho que sólo de esta forma puede hacerse valer. Esté o no esté el acto integrado en un procedimiento, o sea o no un acto del mismo. Por ello se afirma, en ocasiones, que caducan los procedimientos y prescriben, por el contrario los derechos. De tal forma, opina el autor, la mayoría de la doctrina podría estar de acuerdo con la siguiente afirmación: prescripción y caducidad se refieren a la pérdida de una utilidad por el transcurso del tiempo. Pero mientras la prescripción significa una pérdida de un derecho o de sus medios de tutela en general, la caducidad, en sentido estricto, se refiere a un acto concreto determinado por la Ley. Acto que puede encontrar su base en un derecho autónomo que lo tenga como único modo de ejercicio o en un derecho potestativo, facultad o acción que tengan su razón de ser en un derecho subjetivo. De esta forma, la caducidad debe referirse a un acto determinado de ejercicio de un derecho (en el sentido amplio de la palabra) que sólo de esta forma puede hacerse valer. O se realiza este acto o desaparece el derecho. No hay otra forma de defenderlo, y de aquí que no se admita la posibi- 
ción tributaria, como aquel instituto - distinto del de la caducidadque, sin admitir la validez de lo actuado ilícitamente, y fundado en el principio de la seguridad jurídica, extingue la responsabilidad derivada de la comisión de un ilícito tributario, como consecuencia del paso de un tiempo determinado legalmente y la falta de actividad administrativa eficaz dentro de ese término, imposibilitando la posterior actuación de la Administración Tributaria en orden a sancionar, esto es, impidiendo que la Administración competente ejercite su potestad sancionadora tributaria.

\section{I.2. Fundamento de la prescripción extintiva de la infracción tributaria}

Resulta pacífico ${ }^{7}$ considerar que la prescripción ${ }^{8}$ sirve, en general, a la salvaguarda de la seguridad jurídica ${ }^{9}$ —más que en considera-

lidad de otros actos que interrumpen la pérdida del derecho por el transcurso del plazo fijado. FERREIRO LAPATZA, J.J.: Curso de Derecho Financiero Español: Instituciones, Marcial Pons, Madrid,2006, págs. 468-470.

7 RUÍZ RESCALVO, cita a CAZORLA PRIETO, PUGLIESE, PÉREZ DE AYALA,J.L. y EUSEBIO GONZÁLEZ, como defensores del fundamento de la prescripción en el principio de seguridad jurídica. SÁINZ DE BUJANDA, considera que el principio de jerarquía normativa es el instrumento más apropiado para garantizar la seguridad jurídica y, simultáneamente, limitar la posible arbitrariedad de los órganos del Estado. RUÍZ RESCALVO,M.P.: La prescripción ...op. cit.,págs. 55 y 56.

8 MUÑ́́Z BAÑOS califica a la prescripción como PRINCIPIO DE LA PRESCRIBILIDAD. MUÑ́́Z BAÑOS,C.: Infracciones tributarias y delitos contra la Hacienda Pública, Edersa, Madrid, 1996.

${ }_{9}$ En materia penal existen justificaciones variadas, así la de quienes defienden la renuncia del Estado al ius puniendi, la del derecho de los ciudadanos a un proceso sin dilaciones indebidas, o la de la seguridad jurídica o la represión de la inactividad de las autoridades y funcionarios encargados de la persecución de los delitos, o apelaciones a la preservación del derecho de defensa de los imputados o para reducir el riesgo de error judicial en la valoración de la prueba o la pérdida de la función de prevención especial —resocialización — de la pena tardía o por el escaso efecto de prevención general negativa -intimidatorio- . Todo ello lleva a RAGUÉS a decantarse por la naturaleza múltiple del instituto de la prescripción. RAGUÉS I VALLÉS, R.: La prescripción penal: fundamento y aplicación, Atelier, Barcelona 2004, págs. 24-40; Es criticable que, en ocasiones, se haya ligado el fundamento de la prescripción a la subjetiva intención o voluntad del órgano administrativo de abdicar o renunciar, siquiera implícitamente, al ejercicio de su derecho a sancionar (STS 27.05.1992) [ o asimilándola a institución que responde a la común razón de la presunción de abandono del derecho y de las acciones que son su consecuencia (SsTS 8.03.2000, 24.03.2000; ATS 14.03.2000)]. En realidad, la prescripción, más que en un fundamento subjetivo de abandono, no presumible en principio y de muy difícil indagación, se basa en la objetiva inactividad del ejercicio del ius puniendi por parte de la Administración, lo que es fácilmente constatable...La prescripción opera, por tanto, abstracción hecha de cuál pueda ser la intención o voluntad del órgano competente para sancionar (STS 22.01.1990). DE DIEGO DÍEZ, L.A.: Prescripción y caducidad en el Derecho administrativo sancionador, Bosch, Barcelona, 2006, págs. 25-27.

(C) UNED. Revista de Derecho UNED, núm. 24, 2019 
ciones de estricta justicia material-, evitando la protección indefinida de los derechos que ni se ejercitan por su titular, ni se reconoce su existencia por el obligado. Nos encontramos, pues, ante una figura que trata de eliminar la incertidumbre ${ }^{10}$ en el tráfico jurídico o, lo que es lo mismo, procurar la certeza del Derecho. El Tribunal Supremo, en Sentencia de 26 de noviembre de 1988, ya juzgó que la prescripción de las acciones debe ser entendida como una limitación al ejercicio tardío de los derechos en beneficio de la seguridad jurídica y no como un instituto fundado en la justicia intrínseca. La prescripción sirve, pues, para dar certeza a las relaciones jurídicas, especialmente a las patrimoniales, inspirándose por ello en la idea de sanción a las conductas de abandono, negligencia o indiferencia en el ejercicio de los propios derechos ${ }^{11}$.

En este orden de cosas, el fundamento de la prescripción en materia de infracciones y sanciones depende de la teoría de la pena que se adopte, que puede llevar a afirmar la innecesariedad de la sanción, transcurrido cierto período de tiempo, por razones de prevención especial (la sanción es innecesaria si quien cometió la infrac-

${ }^{10}$ Los abogados expertos en derecho fiscal y penal advierten de que retirar la prescripción del delito fiscal para las rentas detectadas en cuentas en el extranjero podría vulnerar la Constitución Española (CE) y supone una medida contradictoria con la amnistía fiscal aprobada la pasada semana... El experto señaló que la retirada de la prescripción de estos delitos podría provocar que la gente que iba a regularizar se retracte y prefiera mantener el dinero en el extranjero «de por vida». "Suprimir la prescripción plantea serios problemas de seguridad jurídica», apuntó Bravo... Por otro lado, Aguilar consideró que la medida es «absolutamente contradictoria» con la amnistía fiscal aprobada la semana pasada, ya que la persona que pretende regularizar se quedaría sin seguridad jurídica ante posibles inspecciones de ejercicios ya prescritos... Sin embargo, Rodríguez incidió en que retirar la prescripción plantea un "problema» de defensa de los derechos fundamentales y está en desacuerdo con el derecho constitucional y penal. En este sentido, el abogado puso como ejemplo que, en caso de que la Justicia reclame deudas fiscales de hace diez años, el afectado se podría encontrar en situación de indefensión por haber perdido los documentos... Los expertos coincidieron en afirmar que la retirada de la prescripción atentaría contra el artículo 9.3 de la CE que «garantiza que el principio de legalidad, la jerarquía normativa, la publicidad de las normas, la irretroactividad de las disposiciones sancionadoras no favorables o restrictivas de derechos individuales, la seguridad jurídica, la responsabilidad y la interdicción de la arbitrariedad de los poderes públicos».DIARIO LA LEY: «Los fiscalistas advierten de la posible inconstitucionalidad de la no prescripción fiscal», Diario La Ley, núm. 7839, Sección Hoy es Noticia, 17 Abr. 2012, Año XXXIII.

${ }_{11}$ Transcurrido un plazo razonable, fijado por la norma, desde la comisión del delito, la pena ya no es precisa para la pervivencia del orden jurídico, ya no cumple sus finalidades de prevención social (STS 08.07.1997); Estas observaciones preliminares deben permitir diferenciar con claridad los comportamientos por principio impunes, de aquéllos inicialmente punibles pero prescritos por el transcurso del tiempo. RAGUÉS I VALLÉS, R.: La prescripción ...op. cit, pág. 23. 
ción lleva tiempo sin reincidir), de prevención general (la pretensión punitiva se debilita y termina por considerarse inconveniente su ejercicio), o de retribución (el tiempo todo lo borra en la conciencia de los hombres, y la Ley no hace más que consagrar ese olvido real reconociéndole efectos extintivos $)^{12}$.

En el Derecho Administrativo sancionador, podemos afirmar ${ }^{13}$, que la prescripción tiene un doble fundamento, según lo veamos desde la perspectiva del ciudadano o de la Administración. Para el primero, la prescripción supone una garantía de seguridad jurídica, pues el administrado tiene derecho a conocer con certeza hasta qué momento es perseguible el ilícito que cometió y se traduce en una contigüidad o inmediación temporal entre la comisión de la infracción y la imposición de la sanción. Para la Administración, la prescripción es una exigencia derivada del principio de eficacia administrativa, respondiendo a la necesidad de "pasar página», pues la Administración no puede estar pendiente de lo que sucedió años atrás, máxime cuando las infracciones administrativas no despiertan, por lo general, la alarma social propia de un delito.

Siempre la prescripción supone una tensión entre los principios de justicia —que exigen el cumplimiento- y de seguridad jurídica -que justifica que las relaciones jurídicas no se mantengan perpetuamente abiertas ${ }^{14}$ - Ante todo, es importante no perder de vista que la «conversión en pasado» ${ }^{15}$ de los acontecimientos como fundamento de la prescripción, define únicamente aquel momento a partir del cual la eventual imposición de la sanción resulta totalmente innecesaria y, por tanto, ilegítima. Así, en la fijación de los concretos plazos el legislador está vinculado por un límite que no puede rebasar legítimamente, el del momento en que el hecho pasa a ser percibido como "pasado»y, por tanto, deja de ser necesaria su sanción. Sin embargo, por debajo de este límite el propio legislador goza de un margen de libertad para eximir del castigo a determinados hechos cuando haya transcurrido cierto tiempo desde su comisión ${ }^{16}$.

12 ALMUDÍ CID,J.M.: «Actuaciones inspectoras e interrupción de la prescripción de la acción para sancionar», $Q F$,núm. 17,2001; FALCÓN Y TELLA,R.: La prescripción ...op. cit.págs. 256 y ss; ORENA DOMÍNGUEZ,A.: Infracciones y sanciones tributarias: Un estudio jurisprudencial, Universidad del País Vasco,2002,pág. 290.

${ }^{13}$ CABALLERO SÁNCHEZ,R.: Prescripción y caducidad en el ordenamiento administrativo, Mc Graw-Hill, Madrid, 1999, págs. 412-413.

${ }^{14}$ CALVO ORTEGA,R.:Curso de Derecho...op. cit.,2010, pág. 242.

15 Según la STC 157/1990, de 18 de octubre, determinar el régimen jurídico de la prescripción de las infracciones penales es algo que corresponde hacer al legislador, de acuerdo con los criterios de política legislativa y de seguridad jurídica que considere idóneos en cada momento.

16 RAGUÉS ... 2004.op. cit.pág. 51. 
Así, en el ámbito sancionador, la prescripción descansa en el principio de seguridad jurídica, al igual que ocurre en el procedimiento de liquidación, o más ampliamente en el ámbito civil ${ }^{17}$, de modo que el paso del tiempo dificulta ${ }^{18}$ la investigación de la infracción y crea una confianza en que la misma ya no será sancionada ${ }^{19}$. De este modo, el fundamento de la prescripción debe venir, forzosamente, de la justificación a la alteración del principio de justicia que deja de aplicarse para ceder, en este caso, ante el principio de seguridad jurídica, evitando una pendencia indefinida ${ }^{20}$, de modo que el tiempo constituye un límite al ejercicio de las potestades administrativas que corresponden al mismo poder que las otorga ${ }^{21}$.

La prescripción de las infracciones y sanciones, aparece ${ }^{22}$ reforzada por la exigencia de reserva de ley contemplada en los artículos 25.1 y 53.1 de la CE. En dichos principios se consagra el principio de legalidad en materia sancionadora de la Administración Pública. Esta reserva de ley prohíbe la remisión de la Ley al Reglamento sin una previa determinación de los elementos esenciales de la conducta antijurídica en la propia Ley. Así, el art. 25.1 CE consagra, cualquiera que sea el ámbito de manifestación del ius puniendi del Estado - penal o administrativo-, el principio de reserva de ley en materia sancionadora que comprende una doble garantía (STC

17 El TEAC, en su Resolución de 10 de marzo de 1999, ha señalado lo siguiente: «La prescripción es una figura jurídica que trata de evitar que la Administración pueda ejercitar sus derechos «sine die» y que pretende crear una situación de seguridad jurídica para el administrado».

18 Tales plazos simplemente representan un límite establecido por el Estado para determinar cuánto tiempo conviene invertir en la persecución de las presuntas infracciones, en la certeza de que, pese a que no todas ellas lleguen a ser finalmente castigadas. RAGUÉS ... 2004.op. cit.pág. 53.

19 ANEIROS enumera las teorías que la fundamentan, así la falta de necesidad de pena una vez que ha transcurrido un período de tiempo (AGUADO I CUDOLÁ,V.), las dificultades de prueba que se producen cuando existe un amplio lapso temporal entre los hechos y su enjuiciamiento (PEÑA GARBÍN), o basándose en la seguridad jurídica, pues, en un determinado momento, el legislador estima que es más importante que la justicia, y por el efecto invalidador del tiempo sobre los acontecimientos humanos. (FALCÓN Y TELLA, ANEIROS). ANEIROS PEREIRA,J.: Las sanciones...op. cit.pág. 153.

${ }^{20}$ FERNÁNDEZ JUNQUERA,M.: La prescripción de la obligación tributaria. Un estudio jurisprudencial, Aranzadi, Pamplona, 2001, págs. 17-19.

${ }^{21}$ A este órgano compete valorar la relevancia que tiene para el interés público mantener en el tiempo las potestades orientadas a su consecución. AGUADO i CUDOLÁ,V.: Prescripción y caducidad en el ejercicio de potestades administrativas, Marcial Pons, Madrid,1999, págs. 23 y 24.

22 RUÍZ RESCALVO,M.P.: La prescripción ...op. cit.pág. 59 y 62; SsTC 61/1990 (FJ7), 83/1990 (FJ2), 207/1990 (FJ3),305/1993 (FJ3), 341/1993,6/1994 (FJ2),145/1995 (FJ3),153/1996 (FJ3),116/1999,292/2000 (FJ15), entre otras. 
$276 / 2000)^{23}$. La primera, de orden material y de alcance absoluto, se traduce en la imperiosa exigencia de predeterminación normativa de las conductas ilícitas y de las sanciones correspondientes, es decir, en la existencia de preceptos jurídicos (lex previa) que permitan predecir con el suficiente grado de certeza (lex certa) dichas conductas. La segunda, de carácter formal, se refiere al rango necesario de las normas tipificadoras de aquellas conductas y sanciones, por cuanto el término «legislación vigente», contenido en el artículo $25 \mathrm{CE}$, es expresivo de una reserva de ley en materia sancionadora.

De acuerdo con la doctrina reiterada del Tribunal (entre otras muchas, SsTC 104/2009, de 4 de mayo, FJ 2; 135/2010, de 2 de diciembre, FJ 4; 144/2011, de 26 de septiembre, FJ 4; 90/2012, de 7 de mayo, FJ 4; y 13/201324, de 28 de enero, FJ 2) el art. 25.1 CE, que in-

${ }^{23}$ También las SsTC 42/1987, 101/1988, 29/1989, 69/1989, 219/1989, 61/1990, 83/1990, 207/1990, 6/1994, 145/1995, 153/1996 y 133/1999.

${ }^{24}$ (FJ3) De acuerdo con la doctrina que se acaba de exponer, para apreciar si la remisión al reglamento que efectúa el apartado séptimo del art. 16.2 b) de la Ley 20/1998 de la Comunidad de Madrid es acorde con el art. 25.1 CE debemos comprobar si el precepto legal que efectúa esta remisión define los elementos esenciales de la conducta antijurídica o si, por el contrario, está remitiendo a la potestad reglamentaria una tipificación autónoma de infracciones, lo que determinaría la inconstitucionalidad del precepto por no respetar la garantía formal que se deriva del principio de legalidad sancionadora. Así lo hemos hecho en otros supuestos en los que la ley defería al reglamento la concreción de algunos de los elementos de la conducta típica. Por ejemplo, en la STC 3/1988, de 21 de enero, consideramos que el art. 9 del Real Decreto-ley 3/1979 de 26 de enero, sobre seguridad ciudadana, que disponía que podía ser sancionado «el incumplimiento de las normas de seguridad impuestas reglamentariamente a las Empresas para prevenir la comisión de actos delictivos» no vulneraba el art. 25.1 CE, pues consideramos que dicho precepto cuestionado fijaba suficientemente los elementos esenciales del ilícito administrativo, al concretar «el desvalor de las conductas consideradas ilícitas en la referencia al incumplimiento por las Empresas de normas de seguridad teleológicamente encaminadas a la prevención de hechos delictivos, normas de seguridad que vendrán luego determinadas en sus circunstancias particulares por reglamentos que responderán, en cada caso, a valoraciones de carácter técnico y contingente, efectuadas por la Administración» (FJ 10). Por las mismas razones, la STC 246/1991, de 19 de diciembre, FJ 3, desestimó un recurso de amparo en el que se aducía, entre otros motivos, que la sanción impuesta en virtud de lo establecido en también en el art. 9 del Real Decreto-ley 3/1979 legal vulneraba su derecho fundamental a la legalidad sancionadora. También se planteaba una cuestión similar en la STC 25/2002, de 11 de febrero. Esta Sentencia resolvió un recurso de amparo en el que se aducía, entre otras cosas, que la norma que servía de cobertura a la sanción impuesta, el art. 91 de la Ley 25/1964, no satisfacía las exigencias del principio de legalidad formal que garantiza el art. 25.1 CE. El Tribunal desestimó esta queja por entender que, al margen de que fuera una norma preconstitucional, el referido precepto, que establecía que «la infracción de preceptos legales y reglamentarios» sobre determinadas materias, entre otras, sobre "registro y comunicación de datos» $\mathrm{y}$ "condiciones de seguridad técnica o sanitaria del personal», tipificaba los elementos esenciales de la conducta por la que fue sancionada la entidad demandante de amparo. Y a la misma 
conclusión llegamos en la STC 104/2009, de 4 mayo. En esta Sentencia entendimos que el art. 91 b) 1 de la Ley 25/1964, de 29 de abril, de energía nuclear, en la redacción dada por la disposición adicional quinta de la Ley 54/1997, de 27 de noviembre del sector eléctrico, en el que se establece que constituye infracción grave «el incumplimiento de los preceptos legales o reglamentarios aplicables o de los términos y condiciones de las autorizaciones o documentos oficiales de explotación, cuando no constituya falta muy grave, salvo los de escasa trascendencia» es acorde con las garantías formales y materiales que se derivan del art. 25.1 CE. En este caso sostuvimos que «la infracción grave tipificada en el art. 91 b). 1 de la Ley de energía nuclear delimita los elementos esenciales de las conductas antijurídicas sancionadas, pues no sólo contiene la acotación del ámbito al que se refieren las normas reglamentarias y las autorizaciones o documentos oficiales de explotación a que se refiere la remisión, que es la actividad desarrollada en las instalaciones nucleares y radioactivas, así como la identificación de los sujetos que pueden cometer la infracción, esto es, las empresas que realicen dicha actividad (art. 91, inciso primero, de la Ley de energía nuclear), sino que, además, mediante la integración del precepto cuestionado con el art. 91 a) de la propia Ley al que indirectamente se remite ("cuando no constituya falta muy grave"), se enuncia el bien jurídico protegido, y se describe suficientemente en qué consiste la conducta infractora, por lo que la remisión a las normas reglamentarias y a los términos y condiciones de las autorizaciones o los documentos oficiales de explotación, satisface plenamente la garantía formal del art. 25.1 CE, al tratarse de una regulación complementaria y claramente subordinada a la Ley.» Por el contrario, hemos considerado que la remisión de la ley al reglamento no satisfacía las exigencias del art. 25.1 CE cuando esta remisión se efectuaba sin una «definición básica de la conducta prohibida en la propia ley» (SSTC 60/2000, de 2 de marzo, FJ 4 y 26/2005, de 14 de febrero, FJ 4). Por esta razón, la última Sentencia citada consideró que el art. 8 de la Ley 38/1985, de 22 de noviembre, del monopolio fiscal de tabacos que, en su apartado 3, disponía que «mediante normas reglamentarias» se establecería «el régimen sancionador» y en su apartado 4 establecía que la Delegación del Gobierno podría sancionar a los expendedores cuando incurrieran las infracciones que se determinaran en el reglamento que desarrollaba la ley era contrario al principio de legalidad sancionadora en su vertiente formal. De igual modo en la STC 81/2009, de 23 de marzo, anulamos el art. 69.3 c) de la Ley 10/1990, de 15 de octubre, del deporte, en el que se establecía que eran infracciones leves «todas las acciones $\mathrm{u}$ omisiones no tipificadas como infracciones graves o muy graves en el presente Título y que sean contrarias a las normas y reglamentos aplicables a los espectáculos deportivos», al apreciar que no contenía los elementos esenciales de la conducta antijurídica, por lo que permitía una regulación reglamentaria independiente, lo que era contrario a las exigencias de legalidad formal que se derivan del art. 25.1 CE. 4. El art. 16.2 de la Ley 20/1998, de ordenación y coordinación de los transportes urbanos de la Comunidad de Madrid establece que constituye infracción administrativa grave el incumplimiento de las «condiciones esenciales de la autorización o licencia», cuando no tenga la consideración de infracción muy grave. Se refiere a continuación a seis condiciones esenciales, acotando el ámbito material que a cada una le corresponde, sin perjuicio del correspondiente desarrollo reglamentario... Ciertamente, el concepto jurídico indeterminado "condiciones esenciales de la autorización o licencia» es un parámetro legal que en alguna medida orienta al reglamento. No obstante, en ausencia de más determinaciones legales, constituye una laxa e insuficiente guía normativa desde la perspectiva del principio de legalidad sancionadora. Con ello está permitiendo que la Administración lleve a cabo una tipificación ex novo de conductas ilícitas vulnerando de este modo la garantía formal del principio de legalidad sancionadora. Debe pues afirmarse que los elementos esenciales de la conducta antijurídica no están identificados en la Ley y por ello la entera definición de esos "elementos esenciales» es la que se enco- 
corpora la regla nullum crimen nulla poena sine lege, comprende una doble garantía, formal y material. La garantía material, como señaló la STC 242/2005, de 10 de octubre, FJ 2, deriva «del mandato de taxatividad o de lex certa y se concreta en la exigencia de predeterminación normativa de las conductas ilícitas y de las sanciones correspondientes, que hace recaer sobre el legislador el deber de configurarlas en las leyes sancionadoras con la mayor precisión posible para que los ciudadanos puedan conocer de antemano el ámbito de lo proscrito y prever, así, las consecuencias de sus acciones» (en el mismo sentido, entre otras muchas, SSTC 104/2009, de 4 de mayo, FJ 2; 144/2011, de 26 de septiembre de 2011, FJ 4; y 90/2012, de 7 de mayo, FJ 4). Por esta razón, como también señala la citada STC 104/2009, de 4 de mayo, FJ 2, «la garantía material implica que la norma punitiva permita predecir con suficiente grado de certeza las conductas que constituyen infracción y el tipo y grado de sanción del que puede hacerse merecedor quien la cometa, lo que conlleva que no quepa constitucionalmente admitir formulaciones tan abiertas por su amplitud, vaguedad o indefinición, que la efectividad dependa de una decisión prácticamente libre y arbitraria del intérprete y juzgador».

La garantía formal, como señala la STC 166/2012, de 1 octubre, FJ 5, hace referencia al rango necesario de las normas tipificadoras de esas conductas y sanciones y sostiene, siguiendo la constante jurisprudencia de este Tribunal, que el término "legislación vigente» contenido en el art. 25.1 CE es expresivo de una reserva de ley en materia sancionadora (por todas STC 77/2006, de 13 de marzo, FJ único y jurisprudencia allí citada).

No obstante, este Tribunal ha señalado también (entre otras muchas, STC 26/2005, de 14 de febrero, FJ 3) que en relación con «las infracciones y sanciones administrativas el alcance de la reserva de Ley no puede ser tan riguroso como lo es por referencia a los tipos y sanciones penales en sentido estricto, y ello tanto "por razones

mienda al poder reglamentario en contra del art. 25.1 CE. Por otra parte, debe señalarse que, como sostuvimos en la STC 132/2001, de 8 de junio, en un supuesto en el que se recurría en amparo una sanción impuesta a un taxista, la relación administrativa que une al Ayuntamiento de Madrid con el sancionado no determina modulación alguna del derecho a la legalidad sancionadora. Ello porque «ningún precepto constitucional prevé, ni explícita ni implícitamente, la limitación de derechos constitucionales en un ámbito de actividad económica privada, aunque esté intervenida y reglamentada, como es la prestación de servicios de transporte en auto-taxi». Por esta razón, «con independencia de cómo se denomine la relación que une al titular de la licencia de auto-taxi con su Ayuntamiento, no hay fundamento alguno para que la sanción impuesta al recurrente carezca de la cobertura legal que, con carácter general, exige el art. 25.1 CE», conclusión que reafirmamos en este caso.

(C) UNED. Revista de Derecho UNED, núm. 24, 2019 
que atañen al modelo constitucional de distribución de las potestades públicas" como "por el carácter en cierto modo insuprimible de la potestad reglamentaria en ciertas materias, bien, por último, por exigencias de prudencia o de oportunidad" (STC 42/1987, de 7 de abril, FJ 2)». Por esta razón es doctrina constitucional reiterada, por todas, STC 242/2005, de 10 de octubre, FJ 2, que la garantía formal, a diferencia de la garantía material, cuyo alcance es absoluto, «tiene una eficacia relativa o limitada en el ámbito sancionador administrativo, toda vez que no cabe excluir la colaboración reglamentaria en la propia tarea de tipificación de las infracciones y atribución de las correspondientes sanciones, aunque sí hay que excluir el que tales remisiones hagan posible una regulación independiente y no claramente subordinada a la Ley». De ahí que en la citada STC 242/2005, de 10 de octubre, FJ 2, se sostenga que «la garantía formal implica que la ley debe contener la determinación de los elementos esenciales de la conducta antijurídica y al reglamento sólo puede corresponder, en su caso, el desarrollo y precisión de los tipos de infracciones previamente establecidos por la ley (por todas, SSTC 161/2003, de 15 de septiembre, FJ 2, o 26/2005, de 14 de febrero, FJ 3).» En definitiva, como ha señalado la STC 104/2009, de 4 de mayo, FJ 2, lo que el art. 25.1 prohíbe «es la remisión de la ley al reglamento sin una previa determinación de los elementos esenciales de la conducta».

La cuestión sobre si el régimen de prescripción de las infracciones administrativas debe, también, contenerse en norma con rango de ley, en razón de la citada reserva constitucional de carácter formal, históricamente, la jurisprudencia fue rigurosa ${ }^{25}$ en la exigencia del principio de legalidad stricto sensu (STS 19.10.1983). Estos planteamientos quiebran con la STC 29/198926, cuando afirmó que del artículo 25.1 CE no se deriva inequívocamente una reserva de ley para la regulación del plazo de prescripción de las sanciones administrativas, de suerte que la exigencia del principio de legalidad en esta materia queda cumplida mediante el establecimiento de plazos de prescripción específicos por la vía de una norma reglamentaria, asumiendo así la tesis de que estamos ante una materia secundaria (STS 6.04.1990). De igual modo, la exigencia de reserva legal constitucionalmente establecida, no invalida las normas reglamentarias

${ }^{25}$ En igual sentido MESTRE DELGADO, quien estableció que los reglamentos no son instrumentos aptos para suplir las omisiones legislativas en materia de prescripción. O BELTRAN AGUIRRE, que sostiene la improcedencia de configurar ex novo, mediante un reglamento, plazos de prescripción de infracciones administrativas. DE DIEGO DÍEZ, L.A.....op. cit.págs. 30-31.

${ }^{26}$ Así las SsTS 27.03.1998, 6.05.1998, 16.05.2000, 3.07.2000 y 24.07.2000. 
anteriores a ella, dictadas válidamente en el marco del sistema a la sazón vigente, sino que dicha reserva opera sólo a partir de la vigencia de la Constitución, sin efecto retroactivo, por aplicación del principio tempos regit actum (STC 305/1993).

Por último, la exigencia de lex praevia ha llevado siempre consigo la peculiar configuración del juego de la retroactividad e irretroactividad en el ámbito sancionador, muy distinto del que tiene en el resto del ordenamiento jurídico. En el ámbito del ius puniendi la irretroactividad de la norma, en cuanto tenga de odiosa y perjudicial, se impone con carácter absoluto, no dispensable por el legislador, por mor del artículo 9.3 $\mathrm{CE}$, aunque dicho artículo lo que prohíbe es la retroactividad de las disposiciones sancionadoras no favorables, lo que a sensu contrario puede entenderse que la Constitución garantiza la retroactividad de la ley penal más favorable (SsTC 8/1981, 15/1981, $51 / 1985,131 / 1986,21 / 1993,215 / 1998)$. De este modo la norma posterior más favorable al inculpado deberá ser de aplicación bien por tipificar el hecho como infracción de menor gravedad, imponer una sanción más benigna, establecer un plazo inferior de prescripción que le favorezca, entre otras circunstancias (SsTS 10.03.1987, 22.1.1991). Esta retroactividad in bonum no se detiene ante la definitiva resolución administrativa, sino que su aplicación va más allá, y alcanza a la vía de los recursos administrativos o jurisdiccionales, llegando hasta la fase de ejecución de la sanción - siempre que no se hubiere ejecutado íntegramente- (SsTS de 13 y 26.3.1992). Así las cosas la retroactividad desfavorable de las normas sobre prescripción no puede aplicarse sin menoscabar el artículo $9.3 \mathrm{CE}^{27}$.

\section{I.3. Naturaleza de la prescripción extintiva de la infracción tributaria}

Debemos señalar con Aneiros ${ }^{28}$ que no es una cuestión pacífica ${ }^{29}$ la naturaleza de la prescripción, pues se ha objetado que la prescrip-

27 DE DIEGO DÍEZ, L.A.:...op. cit.pág. 40.

28 ANEIROS PEREIRA,J.: Las sanciones ...op. cit.,pág. 153.

${ }^{29}$ En el ámbito penal, merece la pena recordar que, al ser la prescripción una institución "favorable al reo», la jurisprudencia tradicional venía resolviendo las dudas en la aplicación de sus normas reguladoras en un sentido extensivo a su existencia, siguiendo el veterano axioma "favorabilia sunt amplianda, odiosa sunt restringenda» (STC 157/1990, de 18 de octubre , y SsTS de 5 de febrero de 1908, 10 de marzo de 1954, 14 de noviembre de 1957 ,13 de marzo de 1973, 6 y 25 de abril de 1990, 12 y 18 de marzo de 1993 y 21 de abril de 1994).... Como resume CHOCLÁN en su citado trabajo, la prescripción tiene un fundamento constitucional (seguridad jurídica, no dilaciones indebidas, reinserción social...), un fundamento mate- 
ción presenta diferentes contenidos en las diversas ramas del ordenamiento jurídico ${ }^{30}$. Sin embargo, en el ámbito tributario, al igual que en el penal, la doctrina mayoritaria (Morillas Cueva, Boldova Pasamar, Rey González) ${ }^{31}$, al igual que la jurisprudencia ${ }^{32}$, y también nosotros, reconocemos la naturaleza material de este instituto, al que no consideramos un simple obstáculo procesal ${ }^{33}$, lo cual presenta importantes consecuencias - v.gr. con la retroactividad ${ }^{34} \mathrm{de}$

rial o sustantivo (disminución de la necesidad de pena con el paso del tiempo, al borrarse en la memoria social los hechos y disminuir el interés por la pena; presunción de que el delincuente se ha corregido - enmienda - si no ha vuelto a delinquir y presunción también de «expiación» por la zozobra de esperar el castigo hasta que acaece la prescripción) y finalmente un fundamento procesal (tanto indirecto como consecuencia de las razones sustantivas, cuando directo: dificultad de prueba por el transcurso del tiempo). RODRÍGUEZ RAMOS,L.:«La prescripción y la estafa en el "Caso de Los Albertos» (STS 14 de marzo de 2003 ¿Derecho penal figurativo, abstracto o surrealista?», Actualidad Jurídica Aranzadi, núm. 597,2003, BIB 2003\1295.

${ }^{30}$ MERINO JARA,I. y SERRANO GONZÁLEZ DE MURILLO,J.L.: «La prescripción del delito fiscal», Actualidad Jurídica Aranzadi,núm.466,2000,pág. 2.

31 Citados por RAGUÉS ... 2004.op. cit.págs. 69-70.

32 SsTS de 30 de mayo de 1997, de 28 de octubre de 1997 y 16 de noviembre de 1989; Por el contrario, en Estados Unidos (institutes of limitation), la jurisprudencia federal alemana, y la mayoría de la doctrina germana, defienden la naturaleza procesal del instituto, aunque otros autores (Mezger, Rodríguez Ramos) defienden la doble naturaleza, procesal y sustantiva (aunque lo critica LORENZ pues cuando una infracción deja de ser delito no tiene sentido afirmar simultáneamente la falta de perseguibilidad). RAGUÉS ... 2004.op. cit.págs. 69-70.

${ }_{33}$ Otros autores infieren naturaleza procedimental de la prescripción, aunque no obvian su aspecto y significación sustantiva, pues los efectos de la acción irradian a la sanción [pues afecta a la perseguibilidad de la infracción]. La infracción aunque realmente existiera, ya no podría ser castigada, el Estado ha perdido la ocasión de ejercitar el ius puniendi en ese caso concreto..La prescripción de la acción para perseguir una infracción presenta, en fin, una naturaleza mixta o híbrida procedimental-sustantiva. DE DIEGO DÍEZ, L.A.: Prescripción ...op. cit.pág. 24.

${ }^{34}$ La doctrina italiana deduce el principio de irretroactividad, en materia de sanciones administrativas y tributarias, del artículo 25 , segundo párrafo, de la Constitución de 1947, el cual tiene una casi absoluta similitud con el artículo 25.1 de la Constitución Española. La retroactividad de la norma más favorable, si bien se admite en el Derecho Penal italiano, no se admite en el ámbito tributario, en el cual rige el principio «tempus regis actum», en base al artículo 20 de la Ley 4/1929. Este diverso tratamiento se ha basado en que las sanciones penales varían cuando el carácter antisocial de un comportamiento se reduce, mientras que las sanciones fiscales suelen reducirse cuando el legislador elige un medio técnico diverso para sancionar. La Corte Costituzionale ha tenido ocasión de pronunciarse sobre la constitucionalidad del artículo 20 de la Ley 4/1929, y lo ha hecho en sentido afirmativo. Ésta se ha basado en que no atenta contra la igualdad, evita que el evasor fiscal actúe con la esperanza del cambio de legislación, y protege el interés general, que será el de la efectiva recaudación del tributo. La Cour de Cassation francesa ha admitido en los últimos tiempos, la rétroactivité des lois répressives plus douces, considerando que las penas anteriores, más severas, no son ya necesarias. Por otra parte, el reconocimiento de la naturaleza quasi-pénale de las sanciones fiscales provoca, igualmente, la evolución de la jurisprudencia. CORDERO GARCÍA, J.A.:« 
las disposiciones sancionadoras más favorables-. En efecto, la eficacia hacia el pasado de una modificación en los plazos de prescripción, sólo será posible, además de si favorece al sujeto ${ }^{35}$, si consideramos que la prescripción tiene naturaleza sustantiva y no meramente procedimental, del mismo modo que si le atribuimos dicha naturaleza no será necesaria su alegación por las partes al serlo de oficio. En ese sentido, expresamos, con Morillo Méndez ${ }^{36}$, que la prescripción es aplicable en las relaciones materiales de exigencia, mientras que la caducidad es una institución puramente procedimental, que afecta al ejercicio de potestades de esta naturaleza, desprovistas de contenido material o sustantivo.

Por último, debemos establecer la ubicación sistemática del instituto, objeto de análisis, en la estructura de la infracción tributaria, y así en la actual definición de la prescripción forma parte de la punibilidad, pues la antijuridicidad y la culpabilidad son magnitudes que se predican del hecho típico y de su autor en el momento de la comisión y cuya concurrencia no puede verse alterada por el paso del tiempo ${ }^{37}$.

La potestad sancionadora de la administración tributaria: principios reguladores», $J T$,núm.5,2000, pág. 14; Para profundizar sobre el fundamento constitucional de este principio sancionador, debe distinguirse entre la retroactividad de la norma favorable y la irretroactividad de la desfavorable. El primer supuesto, a juicio del Tribunal Constitucional, y frente a la opinión mayoritaria de la doctrina, encuentra su configuración, exclusivamente, en la realización de una interpretación «a sensu contrario» del artículo 9.3 de la $\mathrm{CE}$, mientras que el segundo lo encuentra en el artículo 25 de la CE, por esta razón, la retroactividad de la norma sancionadora favorable no es susceptible de recurso de amparo. A este planteamiento se le ha objetado que existen otros principios que, al igual que el de la retroactividad de la norma más favorable, no se encuentran expresamente reconocidos en el artículo 25, y sin embargo reciben el tratamiento de derecho fundamental. MARTÍNEZ LAGO, M.A.; APARICIO PÉREZ,J; BAENA AGUILAR, A. y GARCÍA DE LA MORA,L.: Delitos e infracciones Tributarias: Teoría y práctica, Lex Nova,Valladolid, 1991, pág. 34.

${ }_{35}$ En general, estos autores apelan al derecho que tiene toda persona a saber, no sólo en qué casos puede ser castigada, sino también con qué penas va a serlo y, además, durante cuánto tiempo podrá ser perseguida y sancionada. Desde esta perspectiva, se entiende que aplicar retroactivamente una prolongación de los plazos sería contrario a la seguridad jurídica, una idea que en ocasiones se apoya en argumentos de naturaleza contractualista. RAGUÉS ... 2004.op. cit.pág. 82.

36 MORILLO MÉNDEZ, A.:» Caducidad y procedimientos tributarios», Gaceta Fiscal, núm.170,1998,pág. 99.

37 El cumplimiento de ambos requisitos no determina todavía el carácter delictivo del hecho, pues con posterioridad pueden surgir circunstancias que influyan de manera tan decisiva en su necesidad de sanción, que ésta puede llegar incluso a desaparecer. Estos presupuestos de la sanción penal, que se encuentran desvinculados del hecho, pero que influyen en la necesidad de su castigo, se ubican en ese cuarto escalón de la teoría del delito que se denomina punibilidad...Así la prescripción no es una institución sustantiva o procesal, de acuerdo con lo términos en que tradicionalmente se ha planteado el dilema, sino un elemento del delito que, al igual que las normas procesales más clásicas, se ubica en la punibilidad. RAGUÉS ... 2004.op. cit.págs. 88-89. 


\section{EL OBJETO DE LA PRESCRIPCIÓN SANCIONADORA EN MATERIA TRIBUTARIA}

Lo que en puridad prescribe no es la acción para imponer sanciones sino la responsabilidad que se deriva de la comisión del ilícito tributario, la cual comporta el no-ejercicio en ese supuesto determinado del ius puniendi de la Administración tributaria y, por ende, la imposibilidad de sancionar la infracción tributaria en cuestión ${ }^{38}$.

Con la nueva Ley 58/2003, de 17 de diciembre, General Tributaria (LGT) parece que se ha zanjado la discusión histórica ${ }^{39}$ sobre si lo que prescribía era la potestad para establecer sanciones, la acción de la Administración o la responsabilidad derivada de la comisión de un ilícito, entendiendo, a juicio de algún autor, que se ha decantado por esta última teoría o si se prefiere por la prescripción de la infracción ${ }^{40} q u e$, a su vez, conlleva la imposibilidad de la Administración tributaria de ejercer la potestad sancionadora.

Compartimos con De Diego Díez, que la prescripción de la infracción -o de la persecución administrativa-, no es la denominación más atinada, pues la infracción cometida por un sujeto no prescribe, no se extingue ni desaparece por el transcurso del tiempo, como tampoco prescribe el delito ${ }^{41}$. A lo sumo, lo que se extingue es la responsabilidad, o mejor aún, la exigencia de responsabilidad pero no la infracción. Para que en Derecho pueda decirse con propiedad que existe responsabilidad por la comisión de un ilícito (penal o administrativo) es precisa una resolución firme que previamente lo declare, mientras tanto, si transcurre el plazo fijado por la ley, lo que prescribe es la acción del Estado para ejercitar el ius puniendi — nacida de un posible delito o infracción-. Dicho en otros términos, la llamada prescripción de la infracción no extingue una responsabilidad previamente declarada, sino la acción para perse-

${ }^{38}$ MAGRANER MORENO,F.J. y MARTÍN LÓPEZ.J.:«El límite temporal de incoación del procedimiento sancionador Tributario: los Artículos 81.6 de la LGT y 209.2 del Proyecto de LGT», $Q F$,núm.20,2003,pág. 13; Sin embargo para MORENO TOSCANO siguiendo al el Profesor DEL CORRAL GUERRERO cuando afirmó que «es importante tener claro que lo que prescribe no es la obligación tributaria, ni la infracción tributaria..., sino las potestades administrativas de liquidar, recaudar y sancionar...». MORENO TOSCANO,J.: «¿Prescriben las infracciones tributarias a los cinco años de su comisión?», $Q F$,núm. 11,1994.

39 Así lo exponen FALCÓN Y TELLA,R.: La prescripción....op. cit.pág. 255; BLASCO DELGADO,C.: La prescripción ...op. cit.pág. 73.

40 ANEIROS PEREIRA,J.: Las sanciones...op. cit.,pág. 154.

${ }^{41}$ Prescribir significa según el Diccionario de la Real Academia Española de la Lengua "concluir o extinguirse un derecho o acción», esto es, hacer que desaparezca o se acabe. DE DIEGO DÍEZ, L.A.....op. cit., págs. 22-23. 
guir y sancionar una posible infracción administrativa aún no probada, por lo que esta prescripción no afecta para nada a la existencia del ilícito administrativo, sino a su perseguibilidad en el procedimiento administrativo sancionador. Cuando se produce la prescripción ya no se pueden dilucidar y depurar responsabilidades penales o administrativas contra el autor o autores, ni tampoco exigirles, en su caso, el cumplimiento de la pena o sanción, por lo que resulta más acertado hablar de prescripción de la persecución o de la acción para sancionar.

El título habilitante del ejercicio de la potestad sancionadora de la Administración lo constituye la violación de una norma tributaria, cuyo incumplimiento se encuentra tipificado como infracción del mismo orden. Lo que se persigue con dicho ejercicio es la represión de estas conductas infractoras mediante la imposición de las sanciones correspondientes ${ }^{42} \mathrm{y}$ no la liquidación del tributo, hecho que constituye el objeto de una facultad distinta de la Administración, ubicada en otro título distinto, el de prescripción de la deuda tributaria, con lo que podemos diferenciar dos poderes autónomos ${ }^{43}$.

La autonomía de cada obligación tributaria - expresamente declarada en el artículo 63.1 de la LGT - y la no accesoriedad de la sanción - prevista en el artículo 25.2 de la LGT-impedirán que los efectos de la interrupción de la prescripción - tanto la relativa a la obligación tributaria, como la referida a las infracciones- puedan extenderse más allá del concepto tributario y del ejercicio ${ }^{44}$ a que afecte la actuación, de la Administración o del particular, dotada de virtualidad interruptiva. En este sentido, la jurisprudencia afirma que la acción administrativa interruptiva de la prescripción ha de realizarse en relación con cada hecho imponible o con cada deuda

42 BLASCO DELGADO,C.: La prescripción...op. cit.pág. 82,; MARTÍN CÁCERES,A.F.:La prescripción ...op. cit.pág. 82.

${ }^{43}$ ANEIROS PEREIRA,J.: Las sanciones...op. cit.pág. 154; Cuestión distinta es si la norma infringida (no la que establece la infracción) debe ser necesariamente una ley o puede ser un reglamento. La respuesta es una ley, ya que la infracción supone la violación de una obligación material o formal (en definitiva, de una prestación forzosa) y ésta sólo puede ser establecida por ley de acuerdo con el art. 31.3 de la CE. CALVO ORTEGA,R.: Curso ....op. cit.,2010,pág. 431.

${ }^{44}$ En el ámbito penal, no existe continuidad delictiva cuando las diferentes conductas falsarias se realizan dentro de un año, postura que se apoya en el art. 305.2 del Código Penal, delito fiscal, estableciendo que a los efectos de determinar la cuantía de la infracción se estará a lo defraudado en cada periodo impositivo, aunque, por otra parte, es conocida por todos la doctrina de la Sala Segunda de no aceptar la tesis del delito continuado en tal infracción criminal. MUÑOZ CUESTA,F.J.: «El delito societario de falseamiento de las cuentas de la sociedad: relación con la falsedad documental. Estudio del art. 290 CP», Repertorio de Jurisprudencia Tributaria, núm. 4, 2005, BIB 2005\841. 
tributaria (SAT de Navarra de 21 de febrero de 1987 y SAT de Valladolid de 8 de abril de 1987), lo que hay que extender a las correspondientes infracciones; sin que interrumpan la prescripción las actuaciones imprecisas, sino sólo las que sean suficientemente concretas respecto al concepto de que se trate (Resoluciones del TEAC de 7 de febrero de 1967 y de 26 de noviembre de 1969).

De conformidad con el art. 3 Real Decreto 2063/2004, de 15 de octubre, por el que se aprueba el Reglamento general del régimen sancionador tributario (RGRST), la aplicación de la regla de la calificación unitaria se realiza en función de la conducta global del obligado tributario, existiendo una infracción por cada tributo, período objeto del procedimiento y por cada una de las infracciones tipificadas en la Ley. No se trataría, por tanto, de una mera cuestión formal ni baladí, sino que puede afectar a la propia existencia de la infracción, a su calificación - unitaria- y a la cuantificación de las correspondientes sanciones ${ }^{45}$.

\section{REQUISITOS DE LA PRESCRIPCIÓN DE LA INFRACCIÓN TRIBUTARIA}

\section{III.1. Consumación de la infracción}

Considerando que la prescripción de la infracción es autónoma respecto de la que afecta a la obligación tributaria, esto es, de la facultad de la Administración Tributaria para liquidar el tributo, y que además se ha delimitado ${ }^{46} \mathrm{el}$ ámbito de aplicación del supuesto al que se refiere el apartado primero del artículo 189 de la LGT, en el sentido de que el plazo de prescripción para imponer sanciones tributarias por la Administración afecta a cualquier tipo de sanción, esto es, tanto a las pecuniarias como a las no pecuniarias, es preciso centrarse en este concreto plazo de prescripción que comienza a computarse a partir del momento en el que se comete ${ }^{47} l a$ infracción.

45 AA.VV. (Coord. PELÁEZ MARTOS, J.M. ${ }^{\text {a }}$ ): Todo procedimiento Tributario 2007-2008, CISS, Valencia,2007,pág. 1034.

${ }^{46}$ La delimitación más sencilla - de la infracción - no es la positiva, la propia del principio de tipicidad y que evidencia la autonomía del Derecho sancionador, sino la negativa. Tal perspectiva se evidencia al intentar contestar la siguiente cuestión: ¿qué incumplimiento tributario no resulta objeto de infracción?. SÁNCHEZ HUETE,M.A.: «Una visión crítica del sistema sancionador de la LGT», $J T, 2006, B I B$ $2006 \backslash 327$.

47 La acción ha de entenderse tanto en sentido positivo como negativo, es decir, acción propiamente dicho u omisión. CAZORLA PRIETO,L.M.: Derecho Financiero y Tributario, Aranzadi, Navarra, 2004, pág. 517. 
En efecto, el artículo $189.2 .^{\circ}$ de la LGT $^{48}$ establece que el plazo de prescripción para imponer las sanciones comenzará a contarse «... desde el momento en que se cometieron las correspondientes infracciones», sin perjuicio de lo que se dirá en relación a la imprescriptibilidad de las ganancias patrimoniales no justificadas y no declaradas.

Por nuestra parte, y con la doctrina ${ }^{49}$ mayoritaria, con carácter general, nos posicionamos de modo favorable a la adopción en el ámbito tributario de este criterio frente al de la teoría del conocimiento —esto es, que el plazo de prescripción comience a computarse cuando la autoridad competente tiene conocimiento de los hechos-, ya que, de este modo, como pone de manifiesto Génova Galván $^{50}$, se evita la incertidumbre que se hubiera derivado de haberse optado por el mismo y se consigue, como también ha señalado Caballero Sánchez ${ }^{51}$, que los ciudadanos puedan «... conocer con certeza cuándo se inicia la prescripción, y se evita que en ciertos casos la teoría del conocimiento ampare sencillamente una burla de la prescripción».

${ }^{48}$ Idéntica exigencia se contempla en los arts. 132.1 del CP y 132.2 de la LRJPAC; Así lo expone BLASCO DELGADO,C.: La prescripción...op. cit., págs. 97 a 100.

${ }^{49}$ Sin embargo, algunos autores, como FUSTER ASENCIO, ha puesto de manifiesto que «dado que el expediente sancionador se sucede temporalmente al curso de las actuaciones de comprobación e investigación, y hasta ese momento se ignora si existe o no infracción, no debería ser sino hasta ese instante cuando comenzara el cómputo de la prescripción, ya que sólo entonces se podría ejercitar la acción», y continúa diciendo que «... si la Ley General Tributaria en la línea «ius privatista» que ha adoptado, hubiera respetado, consiguientemente, la «actio nata» contenida en Derecho Común, la cuestión ni siquiera se plantearía, puesto que el cómputo de la prescripción de la acción para imponer sanciones tributarias se demoraría al momento en que éstas pudieran ejercitarse». FUSTER ASENCIO,C.: El procedimiento... op. cit., págs. 124 y 128.

${ }^{50}$ GÉNOVA GALVÁN, A.: «La prescripción...»,op. cit. pág. 47.

51 CABALLERO SÁNCHEZ, R.: Prescripción y caducidad ...op. cit. págs. 433 y 434: Al respecto, este autor señala que en el ámbito administrativo, el derogado art. 132 de la LRJPAC (hoy art. 30 de la Ley 40/2015, de 1 de octubre, de Régimen Jurídico del Sector Público - LRJSP_-) no recogía cuáles eran las consecuencias externas que provoca que el hecho infractor tardara en aparecer o fueran maliciosamente ocultadas por el sujeto responsable — que sí se regulaban en otras normas como en el Reglamento General de Carreteras de 1994 o en el Estatuto de los Trabajadores-de 1995-, lo que debido a los cortos plazos de prescripción de las infracciones administrativas provocó que el TS aplicara en ocasiones la Teoría del conocimiento; esto es, la prescripción, generalmente, comenzaba desde la comisión de los hechos, pero si éstos tardaban en ser descubiertos por la Administración se tenía en cuenta este segundo momento, aplicándose así la teoría de la "actio nata», consagrada en la prescripción civil. Sin embargo, continuaba señalando el autor de referencia, ahora, tal y como establece el extinto art. 132.2 de la LRJ-PAC (hoy art. 30.2 LRJSP), debe estarse al criterio del día del comisión del los hechos, tal y como venía señalando también la jurisprudencia. 
Interesante resulta delimitar los incumplimientos infractores sancionados, y sobre cada uno adverar su concreta consumación. No obstante, la delimitación más sencilla no es la positiva, la propia del principio de tipicidad y que evidencia la autonomía del Derecho sancionador, sino la negativa. Tal perspectiva ${ }^{52}$ se evidencia al intentar contestar la siguiente cuestión: ¿qué incumplimiento tributario no resulta objeto de infracción?

Por los motivos expuestos, cuando se estudie cuál es el «dies a quo» del plazo de prescripción de la infracción, será preciso determinar, en cada concreto tipo de injusto administrativo, el momento en el que la misma se consuma, ya que será a partir de entonces cuando comenzará a correr el plazo de prescripción. En este sentido $^{53}$, hay que recordar que la consumación se produce cuando se lesiona o se pone en peligro el bien jurídico protegido a través de la tipificación de determinadas conductas en el ámbito tributario, bien jurídico que, en este caso, se identifica con la recaudación de los tributos.

De la regulación de la $L G T$ se evidencia un solapamiento entre el incumplimiento tributario y la infracción, entre la relación jurídicotributaria y la actuación sancionadora. La superación de tal modelo punitivo, apegado al incumplimiento de la obligación precisa de que, en primer lugar, se delimite la infracción en torno al bien jurídico que está llamado a proteger, desterrándose así la función accesoria de la infracción como protectora de la obligación jurídica. En segundo lugar, se ha de partir del hecho de que la sanción no es deuda tributaria y, consecuentemente, no puede ser tratada materialmente como tal, impuesta en un procedimiento tributario y aplicando reducciones basadas en criterios en que prevalecen el interés tributario al sancionador. Lo anterior aboca a que la solución para abordar, sobre todo, las infracciones formales, no está en la letra de su tipificación, sino en efectuar interpretaciones más sustanciales de sus ti-

${ }^{52}$ Idea que defiende SÁNCHEZ HUETE, M.A.: «Elementos para un análisis del sistema de infracciones de la Ley General Tributaria», CT, núm. 132, 2009, pág. 170.

53 El incumplimiento de la relación jurídico tributaria, como base del comportamiento infractor, no es un elemento nocivo o negativo, siempre y cuando: En primer lugar, respete los criterios de predeterminación y seguridad ínsitos en el principio de tipicidad... En segundo lugar, el incumplimiento ha de ser relevante, de acuerdo con la lesión o puesta en peligro del bien jurídico protegido. El incumplimiento, a la hora de configurar la infracción, no ha de ser una mera protección accesoria del Derecho Tributario. La descripción de la infracción no puede ser ajena a los fines y fundamentos propios del Derecho sancionador. No atender a tales criterios sería prescindir de una perspectiva auténticamente punitiva. Pues, el derecho sancionador ocuparía el papel de mero garante de la norma tributaria, tendría una posición de accesoriedad. Ibid.op. cit.pág. 171. 
pos. Tal estado de cosas aboca a que la descripción típica efectuada no es garantía de seguridad, no es propiamente tipificación. Por ello es preciso tener presente que el incumplimiento de la obligación tributaria y la infracción no es una misma cosa. Se trata de un fenómeno diverso cuya diferencia es cualitativa y no cuantitativa. $\mathrm{La}$ infracción precisa, en todo caso, de una acción típica antijurídica, culpable y punible. En tal sentido, la evidencia de un incumplimiento no manifiesta la comisión automática de una infracción. De la misma manera que tampoco un incumplimiento tributario es indicativo, siempre y en todo caso, de una culpabilidad o intencionalidad. El incumplimiento es un dato objetivo y la intención del sujeto no; de ahí que no puede derivarse, sin más, un contenido de culpabilidad.

La imposibilidad de identificar infracción e incumplimiento de la obligación tributaria conlleva que han de tipificarse únicamente determinadas lesiones de valores sociales relevantes, encarnados en la protección a bienes jurídicos. El bien jurídico aparece como requisito material de la significación del incumplimiento tipificado. Pues la esencia de la infracción reside en la imposición de males, lesiones jurídicas, sobre la base de ataques especialmente nocivos contra bienes jurídicos. Negar que las infracciones tributarias defiendan bienes jurídicos, comporta negar que protegen valores socialmente consensuados, el orden ético social imperante, y aboca a entronizar al interés administrativo, al interés individual de la Administración como objeto de protección. La sanción no puede concebirse como un instrumento para que la Administración persiga fines propios. Considerar que todo incumplimiento tributario es infracción aboca a instalar una visión patológica de las relaciones ciudadano-Administración, y un clima de recelos y presunciones impropio de un contexto democrático.

Por otra parte, para determinar el concreto momento de la consumación de los diversos supuestos que se tipifican como infracciones tributarias, será preciso atender a la estructura del tipo infractor, esto es, tener presente si se trata de infracciones de lesión o de peligro del bien jurídico protegido, si consisten en una acción o en una omisión, y si exigen o no un resultado.

También habrá que poner de relieve el diferente modo de operar de la prescripción según nos encontremos ante incumplimiento que pueda encajar como criterio de calificación y como tipo infractor autónomo ${ }^{54}$.

${ }^{54}$ BLASCO DELGADO,C.: La prescripción...op. cit. pág. 93, y ampliamente en págs. 135 a 142 .

() UNED. Revista de Derecho UNED, núm. 24, 2019 
Atendiendo al tenor del artículo 180.1. ${ }^{055}$ de la Ley 58/2003, de 17 de diciembre, General Tributaria, " [u]na misma acción u omisión que deba aplicarse como criterio de graduación de una infracción o como circunstancia que determine la calificación de una infracción como grave o muy grave [no leve] no podrá ser sancionada como infracción independiente» ${ }^{56}$.

En el apartado $1 .^{\circ}$ del artículo 184 LGT se indica que las infracciones se calificarán de acuerdo con lo dispuesto en cada caso en los artículos 191 a 206 [y no hasta el artículo 206 bis] de esta Ley, más, en los apartados $2 .^{\circ}$ y $3 .^{\circ}$ efectúa una serie de definiciones que afectan exclusivamente a dos circunstancias, que sabemos que son de calificación, no porque lo diga el artículo 184 LGT, sino porque en los tipos se ve que funcionan con esa naturaleza, así la ocultación de datos y medios fraudulentos.

En materia de circunstancias de calificación, la LGT ha escogido una técnica compleja que define en el artículo 184, mediante dos circunstancias - agravantes- de calificación, referidas exclusivamente a los medios e instrumentos utilizados en la comisión de la infracción, relegando a cada tipo el resto de circunstancias que pudieran ser de aplicación y, por último, en los propios tipos califican deter-

${ }^{55}$ Renumerado por la Disposición Final Primera del Real Decreto-ley 12/2012, de 30 de marzo, por el que se introducen diversas medidas tributarias y administrativas dirigidas a la reducción del déficit público (disposición no afectada por la declaración de inconstitucionalidad resuelta en la STC 73/2017, de 8 de junio de 2017).

56 Así, si como consecuencia de la comisión de alguna de las conductas definidas en las infracciones tributarias de perjuicio económico no directo de los arts. 198 a 201 LGT, se comete o bien otra infracción tributaria de perjuicio económico directo de los arts. 191 a 197 LGT o bien aquélla constituye un criterio de calificación o graduación de las infracciones tributarias de perjuicio económico directo, el principio del non bis in idem impedirá que se pueda abrir un expediente sancionador por una infracción tributaria de perjuicio económico no directo de los arts. 198 a 201 LGT. RAMÓN DE LA POZA, L.M.: Procedimientos Tributarios. Infracciones y Sanciones, Ediciones Experiencia, Barcelona, 2005,pág. 99; A título de mero ejemplo se puede significar que las infracciones tributarias de los artículos 191, 192 y 193 se solapan con las de los artículos 200 y 201, ya que resulta obvio que los tres primeros incumplimientos pueden ser, perfectamente una consecuencia de los segundos. Y la situación descrita en los mencionados artículos 200 y 201 pueden perfectamente considerarse medios fraudulentos del art. 184.3, y tener, a la vista de este precepto, el tratamiento de calificación de la infracción y no el de conductas infractoras de los mencionados arts. 200 y 201, lo cual, por cierto, pone de manifiesto la discutible desaparición de la distinción de las infracciones tributarias en función de que generen o no perjuicio económico para la Administración, criterio que la exposición de motivos de la Ley considera ufanamente "superado». (en Prólogo de Menéndez Moreno, A) en ANÍBARRO PÉREZ, S. y SESMA SÁNCHEZ,B.: Infracciones y sanciones tributarias, Lex Nova, Valladolid,2005, pág. 12. 
minadas conductas sin manifestar a qué circunstancias de calificación deben la atribuida ${ }^{57}$.

Desde nuestro punto de vista, al margen de los problemas que surgen a la hora de aplicar circunstancias, con incidencia total o parcial (art. 10 RGRST), en la calificación concreta de cada infracción - aunque en caso de concurrencia de circunstancias (art. 9.1. ${ }^{\circ}$ RGRST), o de incrementos (art. 9.2. ${ }^{\circ}$ RGRST), corresponda aplicar la que determine una mayor gravedad de la conducta-, interesa centrar la atención en que, según lo expuesto, la prescripción opera de diferente forma en función de que un incumplimiento se aplique como circunstancia que califica la infracción, supuesto en el que seguirá el régimen prescriptivo aplicable a la conducta infractora inicialmente sancionada, o que la conducta en sí misma constituya un tipo infractor autónomo, caso en el que el plazo de prescripción comenzará a computarse a partir de su comisión.

Por lo que se refiere al diferente plazo de prescripción que la responsabilidad derivada de una conducta tiene en función que la misma sea calificada como infracción o como circunstancia de calificación de la infracción, hay que decir que, según la regulación vigente, son dos los supuestos en los que puede producirse esta duplicidad de calificaciones, y que son la utilización de medios fraudulentos en la comisión de la infracción, regulados en el artículo 184.3 de la LGT, y la ocultación de datos ${ }^{58}$ para la determinación

57 Podemos indicar que cabe de dicho artículo 184.2 LGT una doble interpretación, así la primera que las circunstancias de calificación son las que se refieren exclusivamente a los medios o instrumentos de que se vale el sujeto infractor y sólo tales circunstancias serían todas las que deben considerarse como tales. Otra postura, defiende que no es así, la lista del artículo 184.2 LGT no comprendería todas las circunstancias de calificación y cabría que en los tipos de infracción se regulasen otras diferentes. LAMOCA PÉREZ,C.: Infracciones y sanciones tributarias. Análisis crítico del nuevo sistema de infracciones y sanciones en la Ley General Tributaria, CEF, Madrid, 2005, págs. 182 y 183. LAMOCA se decanta por la primera, así debemos defender en base al tenor del artículo $184.1 .^{\circ}$ LGT que «las infracciones tributarias se calificarán como leves, graves o muy graves de acuerdo con lo dispuesto en cada caso en los artículos 191 a 206 de esta ley», por lo que encontramos en dicho apartado legitimación suficiente para que se regule cada circunstancia en cada tipo. Comenta este autor la existencia de algunos "problemas de coherencia conceptual y sistemática jurídica que planteaban aquellas: falta de definición general, enumeración abierta, reenvío a las circunstancias de calificación reguladas en los tipos, confusión entre circunstancias y tipo o subtipos de la infracción, problemas de incompatibilidad con tipos y criterios de graduación, etc. Algunos de estos problemas vuelven a reproducirse en el caso de los criterios de graduación, si bien más atenuados, y por ello con mejor solución.

${ }^{58}$ La STSJ de Valencia de 27 de julio de 2007 (FJ7) explica que a la vista del acuerdo sancionador, no cabe la menor duda de que el hecho de la sanción, consistente en la no declaración de unos ingresos, constituyen la base fáctica de la sanción y a la vez se utiliza como base para determinar el incremento que se regulariza; lo que vulnera el principio «non bis in idem». 
de la deuda tributaria, recogida en el artículo 184.2. Debemos dejar patente que el pretérito criterio de graduación de resistencia, negativa u obstrucción a la acción investigadora de la Administración Tributaria se le ha otorgado carta de naturaleza como tipo infractor autónomo.

Sin embargo, existen otras circunstancias de calificación que se añaden a las previstas en el artículo 184 LGT, así en las infracciones con perjuicio económico destacamos, el dejar de ingresar cantidades retenidas o que se hubieran debido retener, la base de la sanción (artículos 191, 192 y 193 LGT), circunstancias ésas que no alcanzan la naturaleza de medios fraudulentos (artículos 191, 192 y 193 LGT) ${ }^{59}$, circunstancias que también acontecen en las infracciones sin perjuicio económico.

Así las cosas, una misma conducta recibe una calificación diferente en función de las circunstancias que rodeen a la situación en la que se produzca, y ello implica que, en función de esta calificación, pueda apreciarse y sancionarse en momentos diferentes ${ }^{60}$.

En el supuesto de utilización de medios fraudulentos en la comisión de una infracción ${ }^{61}$, también es posible que esta conducta se tenga en cuenta como criterio de graduación de la sanción o que se tipifique como infracción, aunque a ella no le resulta de aplicación la regla del artículo 180.1 de la LGT.

59 Así la utilización de facturas, documentos, etc., falsos o falseados con incidencia igual o inferior al 10 por 100 de la base, y la incidencia superior al 10 por 100 y hasta el 50 por 100 de la llevanza incorrecta de la contabilidad; también en sus STSJ de Valencia de 17 de febrero de 2006 y 9 de enero de 2007 y RTEAC de 16 de diciembre de 2005 (Unificación Criterio).

${ }^{60}$ BLASCO DELGADO,C.: La prescripción...... pág. 138. Puede decirse que si bien es cierto que en el ámbito penal las circunstancias agravantes pueden apreciarse en tanto que no haya prescrito la responsabilidad derivada del delito que se juzga y que las mismas se tienen en cuenta para la apreciación ele una sanción, no es menos cierto que las circunstancias agravantes que se contemplan en el CP tienen una naturaleza diferente que las conductas que en el ámbito tributario se recogen como criterios de graduación, ya que las agravantes penales en su mayor parte - a excepción de la reincidencia que también se contempla en el ámbito tributario ... son circunstancias que concurren en la realización de la conducta delictiva en sí misma y que de algún modo califican las circunstancias en las que ésta se lleva a cabo, sin que se trate - como sucede en los criterios de calificación o graduación de conductas tributarias- que al margen de la conducta típica calificada como infracción grave, puedan constituir también el tipo de otra infracción calificada como simple (leve).

${ }^{61}$ DÍEZ OCHOA opina que dicha circunstancia únicamente puede resultar aplicable a los artículos 191, 192 y 193, no al 195 LGT. DÍEZ OCHOA, J.M.: Derecho Tributario Sancionador. Comentarios y casos prácticos, CEF, Madrid, 2005, pág. 103. 
La tipificación de estos supuestos como infracción autónoma o independiente ${ }^{62}$ se produce en los artículos 200 y 201 de la LGT. Equivalencias podemos encontrar, respectivamente, entre los apartados $1 .^{\circ}, 2 .^{\circ}$ y $3 .^{\circ}$ del artículo $184.3 .^{\circ}$ LGT con los apartados 1.c), 1.d) y 1.a)1-b)-1.e) del artículo 200 LGT y entre el artículo 184.3.b) LGT con el artículo $201 \mathrm{LGT}^{63}$. En esos se recogen- como infracción tributaria una serie de incumplimientos de las obligaciones de índole contable y registral, entre los que se citan: la inexactitud u omisión de una o varias operaciones en la contabilidad y en los registros exigidos por normas de naturaleza fiscal; la utilización de cuentas con significado distinto del que les corresponde; incumplimiento de llevanza de contabilidad o de los libros o registros establecidos por las disposiciones tributarias; el retraso en más de cuatro meses en la llevanza de la contabilidad de estos mismos libros; la llevanza de contabilidades diversas en relación con una misma actividad y ejercicio económico que no permitan conocer la situación verdadera de la empresa ${ }^{64}$.

${ }^{62}$ El principio de no concurrencia del art. 180 LGT, implica que una misma acción no puede ser valorada como criterio de graduación de infracción e infracción independiente, o como criterio que agrave la calificación de la infracción e infracción independiente. Ello motiva que una infracción tributaria como la del art. 200 LGT, de incumplimiento de obligaciones contables, se vaya a aplicar en pocas ocasiones en la práctica. Utilizada la anomalía contable sustancial como un criterio de calificación ya no es posible sancionar por el art. 200 LGT. RAMÓN DE LA POZA, L.M.: Procedimientos ...op. cit. pág. 23.

${ }_{63}$ El desarrollo de dichos apartados se encuentra en los artículos 11 y 12 del RD 2063/2004, de 15 de octubre.

${ }^{64}$ Para LAMOCA «de los tres grupos de circunstancias reseñadas en el artículo 184.3. ${ }^{\circ}$ LGT, únicamente las conductas de dicho precepto que no alcanzan la consideración de medios fraudulentos, ofrecerían dificultades interpretativas respecto de la incompatibilidad prevista en el artículo 180.2 LGT, dado que las otras dos no darían lugar a supuestos teóricos de incompatibilidades, al no tener tipificación como infracción independiente. Pero tanto la utilización de facturas, documentos, etc.. falsos o falseados, como la llevanza incorrecta de la contabilidad, sí que tienen tipo independiente, artículos 201 y 200, respectivamente, por lo que pudieran dar lugar a un supuesto de incompatibilidad. ¿Qué sucedería si se aplicasen en los artículos 191, 192 y 193 LGT las circunstancias subjetivas citadas cuando no son medios fraudulentos y por tanto no son circunstancias formales? ¿Se daría la incompatibilidad prevista en el artículo 180.2 LGT? Pensamos que sí, puesto que la circunstancia subjetiva y formal está determinando la calificación de la infracción, a pesar de no coincidir exactamente con la descrita en el artículo 180.2, por requerir ésta la superación de unos porcentajes de incidencia con respecto a la base de la sanción. Además... porque de no hacerlo se conculcaría el principio non bis in idem.....». LAMOCA PÉREZ,C.: Infracciones ...op. cit. págs. 185 y 186. Para DÍEZ OCHOA sólo en caso de que no operasen estas circunstancias como criterio de calificación, bien porque no supere el porcentaje del 10 por 100, bien porque estemos en presencia de otra infracción tributaria, las anomalías contables y registrales tendrán la consideración de infracción tributaria independiente (de las previstas en los arts. 191 a 193 LGT), tipificada y regulada en los artículos 200 y 201 de la LGT.. DÍEZ OCHOA, J.M.: Derecho Tributario ...op. cit. págs. 118, 127 y 132. 
Pues bien, el artículo 184.3.b) de la LGT establece lo que se entiende por medios fraudulentos, y entre ellos se incluye, la existencia de anomalías sustanciales en la contabilidad, tal expresión abraza prácticamente los mismos comportamientos a los que se refiere el artículo 11 y 12 RGRST. Por lo tanto, cuando la Administración Tributaria aprecie la existencia de anomalías contables deberá considerar, en primer lugar, si se trata de un expediente por infracción grave o muy grave, en cuyo caso la conducta será un criterio de graduación de la infracción ${ }^{65}$, y, en segundo lugar, solamente si dicho expediente no procede aperturarlo, la conducta podría ser considerada como un supuesto de infracción tributaria autónoma, sin perjuicio de los supuestos de compatibilidad entre infracciones tributarias ${ }^{66}$.

65 Cuando concurren varias de las circunstancias de calificación (v.gr. facturas falsas y llevanza incorrecta de contabilidad), se tomará, ex art. 9.1.2. ${ }^{\circ}$ RGRST, la que determine una mayor gravedad de la conducta (en nuestro caso, facturas falsas), lo que no habilitará para que se sancione de manera separada (v.gr. por el art. 200 LGT) el resto de circunstancias concurrentes que quedarán absorbidas por el análisis global de la conducta. MESTRE GARCÍA, E. y CERVANTES SÁNCHEZ-RODRIGO, C. J.: Guía de infracciones y sanciones tributarias, CISS, Valencia, 2005, pág. 40 .

${ }^{66}$ Sin embargo, la LGT no resuelve qué ocurre con aquellos incumplimientos contables y registrales que, habiendo sido instrumento para la comisión de las infracciones de los arts. 191 a 193 LGT, por no tener una incidencia sobre la base de la sanción superior a los porcentajes exigidos legalmente, no llevan aparejada la calificación de infracción como grave o muy grave. Pues bien, esta cuestión quedaría resuelta a la luz del art. 16.3 del RGRST, en el sentido de que sólo cabría sancionar por el incumplimiento relativo a la incorrecta declaración o autoliquidación, pero no así por la infracción de los deberes contables y registrales. Con esta previsión se resuelve un problema que se suscitaba en la regulación precedente y que permitía sancionar simultáneamente la infracción simple referente al incumplimiento de las obligaciones contables y registrales y la infracción de dejar de ingresar, aunque aquélla se hubiera efectuado como conducta preparatoria de esta otra infracción. De modo que cuando el incumplimiento de deberes registrales o contables tiene incidencia directa en la incorrecta declaración o autoliquidación se regirá por el art. 16.3 RGRST (hoy art. 16.4 RGRST, según la redenominación dada por el RD 1072/2017, de 29 de diciembre), y cuando dichos deberes nada tengan que ver con los datos declarados o autoliquidados, en este caso podrá aplicarse de manera independiente el art. 200 LGT...Tampoco cabrá sancionar de forma independiente el incumplimiento contable o registral que haya ocasionado una incorrecta declaración o autoliquidación que no genere perjuicio económico, esto es, cuando hubiera dado lugar a la infracción del art. 199 LGT (así la SAN de 26 de noviembre de 2001). ANÍBARRO PÉREZ Y SESMA SÁNCHEZ en la obra colectiva del Profesor CALVO ORTEGA,R. (Dir.), TEJERIZO LÓPEZ,J.M. (coord..).et alii: Los nuevos reglamentos tributarios, Thomson-Civitas,Navarra, 2006, págs. 280 y 281. 
Por lo que se refiere al criterio de calificación consistente en la ocultación de datos para la determinación de la deuda tributaria, esta circunstancia se aplica sobre las sanciones que corresponden a las infracciones graves. En los supuestos de los artículos 191, 192, 193 y $195^{67}$ y $206 b_{i s}{ }^{68}$ LGT no se presentan problemas en relación con la prescripción, ya que la «agravante» se consuma en el mismo momento que el de la infracción grave ${ }^{69}$, esto es, al final del plazo para la realización voluntaria del ingreso, declaración o comunica-

${ }^{67}$ Sin embargo DÍEZ OCHOA opina que dicha circunstancia únicamente puede resultar aplicable a los artículos 191, 192 y 193, no al 195 LGT. DÍEZ OCHOA, J.M.: Derecho Tributario...op. cit. pág. 103; SÁNCHEZ HUETE estima en caso del art. 194 LGT que el tipo de injusto ya comporta por su propia naturaleza la ocultación material, sin necesidad de efectuar remisión alguna al art. 184 de la LGT, por ello no se apreciará dos veces la circunstancia de ocultación. SÁNCHEZ HUETE,M.A.: Las infracciones en la nueva Ley General Tributaria, Marcial Pons, Madrid,2007, pág. 202.

${ }_{68}$ En la infracción grave regulada en el art. 206 bis LGT, se recoge la infracción en supuestos de conflicto en la aplicación de la norma tributaria, y que suponen el incumplimiento de las obligaciones tributarias mediante la realización de actos o negocios «cuya regularización se hubiese efectuado mediante la aplicación de lo dispuesto en el artículo 15 de esta Ley» y en la que hubiese resultado acreditada cualquiera de las (cuatro) situaciones que especifica y aclarando que constituirá infracción tributaria exclusivamente cuando se acredite la existencia de «igualdad sustancial» entre el caso objeto de regularización y aquel o aquellos otros supuestos en los que se hubiera establecido criterio administrativo y éste hubiese sido hecho público para general conocimiento antes del inicio del plazo para la presentación de la correspondiente declaración o autoliquidación. Entendemos dudosa la constitucionalidad de un precepto que considere contravención el uso de la economía de opción, cuando el art. 15 LGT no prevé sanción alguna para dicho supuesto. Recordemos a este efecto que la Exposición de Motivos de la LGT se contempla que «[e]n la sección $3 .^{\text {a }}$, relativa a la «interpretación, calificación e integración de las normas tributarias», se incorpora el precepto que regula la calificación de las obligaciones tributarias y se revisa en profundidad la regulación del fraude de ley que se sustituye por la nueva figura del "conflicto en la aplicación de la norma tributaria», que pretende configurarse como un instrumento efectivo de lucha contra el fraude sofisticado, con superación de los tradicionales problemas de aplicación que ha presentado el fraude de ley en materia tributaria».

${ }^{69}$ Cuando existe ocultación, cuando no se presenten declaraciones o se presenten declaraciones con omisiones o falsedades. La declaración se erige en soporte a través del que se realiza la conducta infractora. Según el artículo 119.1. ${ }^{\circ}$ LGT «se considerará declaración tributaria todo documento presentado ante la Administración tributaria donde se reconozca o manifieste la realización de cualquier hecho relevante para la aplicación de los tributos», todo ello y sin perjuicio del formato o modelo oficial que quepa aprobar para determinados supuestos de declaración, ex artículo 98.3 LGT y 117.1. ${ }^{\circ}$ RGGI. En dicha circunstancia se puede incurrir en cualquier momento, no exigiendo de la falta de presentación en plazo. Además, la ocultación constituye circunstancia de calificación en los tipos de los artículo 191 a 193 LGT — por lo que no ha lugar la aplicación del non bis in idem ex art. 180.2 LGT-, sin embargo, supone un tipo independiente en el caso del artículo 199 LGT. 
ción, y por tanto, los plazos de prescripción de ambas conductas comienzan a correr al tiempo ${ }^{70}$.

De otro lado, existen una serie de circunstancias de calificación añadidas en los tipos de infracciones sin perjuicio económico, que no llevan pareja expresión legal justificativa de la diferente calificación. Así, a determinadas conductas infractoras se las clasifica de un determinado modo, atribuyéndole la Ley esa cualificación especial. En estos supuestos las circunstancias, que permiten atribuir una $\mathrm{u}$ otra calificación a la infracción, quedan desdibujadas, de modo que las mismas ceden a favor de otro tipo de consideraciones de política legislativa que hacen entrever un distinto reproche social que el que pudieran atribuirle las circunstancias de calificación. El hecho de considerar a esas circunstancias, que convierten en especial al tipo, como circunstancias de calificación de la infracción o como tipo independiente, harán que resulte de aplicación la regla del artículo 180.1 LGT o no, nosotros nos decantamos por la primera opción $^{71}$. Supuestos de circunstancias especiales sólo los encontramos en el artículo 194 LGT, en la omisión de datos relevantes como circunstancia especial y distinta de la de ocultación de datos, y la inclusión de datos falsos como distinta de la del empleo facturas, justificantes u otros documentos falsos o falseados. Dicho precepto es el único supuesto en el que la clasificación de un único modo puede deducirse de la calificación de la conducta, a diferencia de la conducta de los artículos 195, 196,197, 198, 199 200, 203, 204 y 206 de la LGT donde la clasificación de la infracción viene dada por definición legal sin justificación alguna ${ }^{72}$. En estos supuestos, según la in-

70 Advierte LAMOCA que el amplio concepto que de declaración se recoge en el artículo 119 de la LGT, hace que si... .se declaran determinadas magnitudes a efectos de un impuesto y esas magnitudes son a su vez variables fiscales de otros tributos, podamos concluir que éstas ya han sido declaradas por el obligado a la Administración, puesto que están en disposición de conocerlas la Administración. Sin embargo, del artículo 4.1 RGRST no se declara en los supuestos expresamente allí descritos, pero a sensu contrario, sí se declara cuando la Administración puede conocer los datos porque ya se los ha facilitado el obligado en otros tributos, v.gr. IVA, I.Soc. Así, de un lado se declara o no se declara a efectos de estimar o no la ocultación. Y de otro, quien no declara los ingresos por un impuesto, alegando que ya lo ha hecho en otro impuesto, estará incumpliendo la obligación de declarar. LAMOCA PÉREZ,C.: Infracciones...op. cit. págs. 191 y 192.

${ }^{71}$ Considera LAMOCA que «sean originarias o no las calificaciones, siempre estaremos ante circunstancias de calificación materiales que se confunden con el tipo, y vienen a ser el propio tipo, y por lo tanto no tendrían la naturaleza formal de calificación, aunque materialmente la tuvieran y pudiesen desencadenar la vigencia del principio non bis in idem. LAMOCA PÉREZ,C.: Infracciones...op. cit. pág. 187.

72 El artículo 201 LGT, para infracción sin perjuicio económico, recogería dos circunstancias de calificación no previstas en el artículo 184 LGT, el incumplimiento de las obligaciones de facturación y la falta de expedición o falta de conservación de las 
terpretación dada, el período de prescripción principiaría desde la consumación del tipo de conducta, con la salvedad del supuesto del artículo 194 LGT, en el que circunstancia y conducta, hemos concluido, permiten conformar un tipo independiente no calificado, sino definido de modo autónomo ${ }^{73}$.

Por último, concluimos que para que comience a correr el plazo de prescripción de la responsabilidad derivada de la comisión de un comportamiento ilícito es preciso que el mismo se haya consumado ${ }^{74}$.

facturas, que permiten calificar como grave la conducta. Además en dicho tipo si se da una circunstancia prevista en el artículo 184.3.b) LGT que califica como muy grave el tipo, la expedición de facturas falsas, no requiriendo que su incidencia sea superior al 10 por 100 de la base de la sanción. Dicho precepto también contiene un supuesto propio de infracción leve, por incumplimiento de las obligaciones relativas a la correcta expedición o utilización de los documentos de circulación exigidos por la normativa de los impuestos especiales. También el artículo 202 recoge dos clases de infracción, leve y grave, de una conducta, incumplimiento de las obligaciones relativas a la solicitud y utilización del número de identificación fiscal o de otros números o códigos, regulando circunstancias distintas de las del artículo 184 LGT. Debemos concluir que en estos dos supuestos, pese a no contemplar circunstancias calificadores del artículo 184 LGT, son ciertamente circunstancias, y en lo relativo a nuestro trabajo, obligan a tener que tomarlas en consideración para determinar si la conducta incluida en dicha circunstancia ha prescrito o no, según califique o no al tipo infractor.

${ }^{73}$ En relación al CP de 1995; con anterioridad al mismo, la Jurisprudencia venía interpretando que en los delitos permanentes o de tracto continuo (como puede ser la ausencia total de contabilidad) la consumación se producía cuando cesaba la situación lesiva para los bienes jurídicos protegidos —STS de 24 enero 1990, en relación con el delito de abandono de familia-, y en los delitos continuados (incomparecencia. reiterado del obligado tributario a los requerimientos que se le formulan) con la última acción incluida en los mismos —STS de 3 febrero 1984_; La actual solución de la LGT, para CABALLERO SÁNCHEZ, R.: Prescripción y caducidad... op. cit., pág. 430, es la lógica, ya que de otro modo el tiempo permitiría brindar una conducta ilícita; En este sentido, el extinto RD 1930/1998 establecía en su art. 14.3 que «el incumplimiento de los sucesivos requerimientos reiterados de idéntico contenido, constituirá una única infracción simple».

${ }^{74}$ Los tributos de "declaración periódica " no son impuestos periódicos sino instantáneos. Son, sin embargo, tributos que gravando, normalmente, cada uno de los actos habituales de una empresa (p.ej. cada una de las ventas que realiza), deben declararse periódicamente (cada tres meses, cada año), incluyendo en cada declaración todos los hechos imponibles (las ventas) realizados en el período. El IVA es, en este caso, el impuesto paradigmático. La referencia contenida en el art. $305.2 \mathrm{CP}$ a «cada uno de los distintos conceptos por los que un hecho imponible sea susceptible de liquidación» impone la incomunicabilidad - a efectos de terminar la cuantía de la cuota defraudada- de las distintas obligaciones que surgen por la realización de cada hecho imponible o por la consumación de cada período impositivo o de cada período de declaración (o de un año si estos período son más cortos) lo que impide - desde luego- la aplicación al delito fiscal de la norma contenida en el art. $74 \mathrm{CP}$ y aplicar al delito fiscal el régimen del delito continuado. La imposibilidad de aplicar el delito continuado en el ámbito del delito fiscal ha sido subrayada por una continua y constante jurisprudencia (SsTS, entre otras, 10/10/2001, 3/1/2003). FERREIRO LAPATZA, J.J.: Curso de Derecho ...2006, op. cit. pág. 570.

(C) UNED. Revista de Derecho UNED, núm. 24, 2019 


\section{III.2. Inactividad del titular del derecho sancionador tributario}

La inactividad del titular del «ius puniendi», en este caso, de la Administración Tributaria, durante un período ininterrumpido ${ }^{75} \mathrm{de}$ cuatro años constituye el segundo de los requisitos que deben concurrir para que comience a correr el plazo de prescripción que afecta a la responsabilidad derivada de la comisión de una infracción tributaria. Este plazo, tal y como establece la norma, se inicia a partir del momento en el que la infracción se comete ${ }^{76}$, al igual que sucede en el Derecho penal o en el ámbito del Derecho administrativo sancionador.

Lo primero que hay que señalar es que la inactividad de la Administración no puede identificarse con la pasividad de la misma, ya que pueden producirse situaciones en las que la Administración interviene pero no con la diligencia que le es exigible y su actuación deviene ineficaz a efectos de la prescripción, o mejor dicho, de su interrupción. Por ello, señalamos, con la doctrina ${ }^{77}$, que resulta más apropiado exigir la ausencia de actividad administrativa eficaz, y no la inactividad de la Administración, pues la competencia es irrenunciable.

Pues bien, son precisamente los supuestos que se sitúan en esa zona intermedia, entre la inactividad total y las actuaciones eficaces dirigidas a conformar una voluntad procedimental — según el concepto clásico de Zanobini (1958)_, las que pueden plantear problemas desde el punto de vista de la interrupción del plazo de prescripción.

${ }^{75}$ El tiempo, en la prescripción y caducidad, como medida de duración, no forma parte de la esencia del fenómeno. Se invoca así el viejo aforismo tempus non est modus constituendi vel dissolvendi iuris. No obstante, si podemos hablar de que prescripción y caducidad son efectos jurídicos que produce el tiempo, en cuanto que es la ley quien atribuye tal eficacia al elemento temporal. AGUADO I CUDOLÀ, V.: Prescripción y caducidad ...op. cit., págs. 35 y 36.

76 De este parecer son FALCÓN Y TELLA, R.: La prescripción...op. cit. pág. 272 y 273. También LOZANO CUTANDA, B.: La extinción...op. cit. págs. 212 y ss. En relación a la infracción continuada v.gr. de falta total o sistemática de contabilidad o resistencia continuada a la acción inspectora), expone FALCÓN Y TELLA que para algunos, como AMORÓS RICA o GÉNOVA GALVÁN, la prescripción no comenzará hasta verificarse la última acción, sin embargo, opina que ello no es posible y cada infracción debe reputarse autónoma a efectos de prescripción, por lo que los plazos han de computarse siempre desde la comisión de correspondiente infracción.

77 AGUADO I CUDOLÀ, V., señala que «más que hablar de inactividad como presupuesto de la prescripción, cabría hablar con mayor propiedad de ausencia de actividad administrativa eficaz, puesto que es posible que haya existido actividad administrativa pero que esta no sea suficiente para interrumpir los plazos de prescripción», diferenciando así entre diversos grados o situaciones de inactividad. AGUADO I CUDOLÀ, V.: Prescripción ...op. cit. pág. 31. 
Por tanto, desde un punto de vista objetivo, para que se produzca la prescripción se requiere la concurrencia de una actividad administrativa ineficaz ${ }^{78} \mathrm{O}$ inactividad administrativa; ahora bien, desde una perspectiva subjetiva es conveniente preguntarse si en esta inactividad o ineficacia de la actuación administrativa interviene, de algún modo, la voluntad de las partes, y en concreto, la voluntad de la Administración que tiene la potestad de sancionar. En este sentido, nos parece acertada la opinión ${ }^{79}$ que sostiene que la prescripción se debe a un hecho totalmente objetivo, como es la inactividad o falta de eficacia de la actuación administrativa, y no a la intención subjetiva o voluntad de renunciar por parte del órgano administrativo al ejercicio de la potestad, ya que esta competencia es irrenunciable y además estamos ante un instituto que se fundamenta en la seguridad jurídica, lo que inicialmente no parece ser muy coherente con dejar a la voluntad de las partes su producción. Esta postura, a juicio de algunos autores, aproxima aún más el régimen de la prescripción y la caducidad en cuanto límite del ejercicio de potestades administrativas ${ }^{80}$. Así, parece más adecuado exigir la ausencia de ac-

78 Parece más adecuado exigir la ausencia de actividad administrativa eficaz, en lugar de inactividad sin más, puesto que de otro modo se estaría concediendo eficacia interruptiva de la prescripción a actuaciones sin contenido sustancial u que sólo persiguen la paralización del cómputo del plazo. ANEIROS PEREIRA,J.: Las sanciones ...op. cit.,pág. 157; Es clásica la cita a la STS de 25 de junio de 1987.JUAN LOZANO,A.M.: La interrupción ...op. cit. págs. 99 y ss.

${ }^{79}$ En este sentido se encuentran los siguientes pronunciamientos del Tribunal Supremo: SsTS de 13 noviembre 1990, 18 febrero 1995, 21 mayo 1997. En esta última sentencia se señala que «el fundamento de la prescripción..., no radica en la subjetiva intención o voluntad del órgano administrativo de renunciar al ejercicio del derecho a sancionar, sino que el fundamento de la prescripción hay que buscarlo en la inactividad de dicho ejercicio por parte de la Administración». Ahora bien, encontramos también pronunciamientos del mismo Tribunal en los que se defiende el planteamiento contrario, como en las SsTS de 20 diciembre 1988 y 22 marzo 1993, de las que se deduce que la voluntad de la Administración es precisamente el elemento que ayuda a discernir la caducidad y la prescripción, de manera que como se señala en el primero de los pronunciamientos citados cuando señala que «la expresada sustentación del Letrado del Estado incurre en el error de confundir el instituto de la prescripción con el de la caducidad. El primero es susceptible de interrupción y depende de la actuación de las partes. En cambio la caducidad sólo depende del transcurso del plazo que la norma establece y no es susceptible de interrupción por ningún motivo».

${ }^{80}$ En efecto, si se tiene presente la voluntad de la Administración, en la prescripción ésta exterioriza su voluntad a través de actuaciones que interrumpen su plazo de consolidación, mientras que la caducidad responde a la producción de un hecho totalmente objetivo sin tomar en consideración la voluntad de las partes. AGUADO I CUDOLÀ, V.....op. cit., págs. 32 y 33; Desde nuestro punto de vista, en un instituto que se fundamenta en la seguridad jurídica no parece razonable que la prescripción dependa de la intención subjetiva de las partes sino que debe de apoyarse en datos objetivos que permitan constatar que la prescripción se ha interrumpido; Para el 
tividad administrativa eficaz, en lugar de la inactividad sin más de la Administración, puesto que de otro modo se le estaría concediendo eficacia interruptiva de la prescripción a actuaciones sin contenido sustancial y que sólo persiguen la paralización del cómputo del plazo $^{81}$.

Varios son, por tanto, los momentos en los que la Administración Tributaria puede permanecer inactiva desde el inicio hasta la resolución del procedimiento sancionador, y sus consecuencias son diversas afectando algunas de ellas al plazo de prescripción que tiene la Administración para sancionar. En este punto, la inactividad que realmente nos interesa, porque constituye uno de los requisitos esenciales para que pueda aplicarse el instituto de la prescripción, es aquella en la que la Administración Tributaria no inicia en los cuatro años siguientes a la comisión de la infracción — sin perjuicio de las posibles interrupciones de este plazo- el procedimiento sancionador, aún con todas las limitaciones temporales — de caducidad en su iniciación y terminación- a las que está supeditada el ejercicio de esta acción.

Por último, debemos dejar constancia de la relevancia que tiene la inactividad del sujeto infractor, ya que una vez consumada la infracción, existe la posibilidad de que el mismo trate de corregir su conducta, al menos en las infracciones que consisten en conductas defraudatorias. En estos supuestos, las consecuencias de la actividad del sujeto serán diversas en función de en qué momento se desarrolle la misma, y en concreto, si se produce antes o después de que haya sido requerido por la Administración para regularizar la situación tributaria. Estos supuestos se producen una vez que el plazo de

autor citado en líneas precedentes «esta diversidad de planteamientos puede ser superada si atendemos a las diferencias existentes entre la voluntad en el ámbito civil y en el administrativo. Cabe señalar que se vienen definiendo por una parte mayoritaria de la doctrina al acto administrativo como una declaración de voluntad, juicio, deseo o de conocimiento, en el ejercicio de una potestad administrativa (...). Esta voluntad debe concebirse como una voluntad procedimental que es el resultado de la ponderación de intereses y de la aportación de los diversos órganos que intervienen, a través de los diversos trámites, en la toma de decisión administrativa, y continúa señalando que «de esta forma será conveniente, en ocasiones, que pueda valorarse la actitud o conducta de la Administración para constatar que se ha producido esta ausencia de actividad administrativa eficaz. En efecto, en algunos casos, puede llegar a existir actuación administrativa exteriorizada de la que tendrá conocimiento su destinatario, pero no por ello debe interrumpirse necesariamente su prescripción. Es el tema (...) de las diligencias que tienen como única finalidad paralizar el cómputo del plazo de prescripción». Ibid.op. cit., pág. 135.

${ }^{81}$ GENOVA GALVÁN, A.: "La prescripción...», op. cit.,pág. 52; JUAN LOZANO, A. M.:La interrupción ...op. cit., págs. 99 y ss. ANEIROS PEREIRA, J..... op. cit. pág. 156. 
prescripción de la infracción ha comenzado a computarse — desde el día en que se consumó la misma-, por lo que habrá que tratarlos como supuestos de interrupción del plazo de prescripción.

\section{III.3. Transcurso del plazo}

La prescripción es un efecto jurídico que la ley reconoce al transcurso del tiempo, con independencia que se considere que el tiempo es o no un elemento esencial de este instituto, por ello resulta preciso determinar el dies a quo - día inicial del cómputo del plazoy el dies ad quem - día final de dicho cómputo- para alcanzar la prescripción $^{82}$.

A nuestro parecer ${ }^{83}$, «en la prescripción el tiempo es la medida objetiva de inacción material de la parte que goza del poder de exigencia, a diferencia de la caducidad en que el tiempo es la medición misma del derecho o de la potestad, puesto que el ejercicio de la misma tiene esencialmente carácter temporal».

El artículo 189 de la LGT, como continuación de su predecesor, el artículo 24 de la Ley de derechos y garantías de los contribuyentes, regula un único plazo ${ }^{84} d e$ prescripción de cuatro años. Así se concreta que la responsabilidad derivada de las infracciones tributarias se extinguirá por el transcurso del plazo de prescripción para imponer las correspondientes sanciones ${ }^{85}$, siendo dicho plazo de cuatro años.

El plazo de prescripción del ejercicio de la potestad para imponer sanciones tributarias ${ }^{86}$, en su aspecto positivo, indica el tiempo den-

82 BLASCO DELGADO,C.: La prescripción...op. cit. págs. 97 a 100.

${ }^{83}$ MORILLO MÉNDEZ, A.: «Caducidad ....»op. cit., pág. 99.

${ }^{84}$ Una abundante exposición de plazos de prescripción del derecho extranjero se puede encontrar en FALCÓN Y TELLA,R.: «La modulación de los plazos de prescripción en función de la conducta del sujeto pasivo», $Q F$, núm. 16, 1996, págs. 5 y 6.

${ }^{85}$ La prescripción es un instituto que se fundamenta de manera casi exclusiva en la seguridad jurídica, y no en la equidad, que aconsejaría mantener indefinidamente abierta la posibilidad de exigir el tributo a quien ha incumplido sus obligaciones, al menos en los supuestos de infracción...Se podría limitar más o menos... pero nunca eliminarla totalmente, ya que...es algo consustancial a la prescripción... si, por definición, la prescripción no puede resultar nunca completamente equitativa, que al menos sirva a la seguridad jurídica que la fundamenta. FALCÓN Y TELLA,R.: «La modulación ....»,op. cit. págs. 5 y 6.

${ }^{86}$ Para AGUADO — siguiendo a DÍEZ PICAZO - lo que prescribe o caduca no son los derechos y potestades, sino las facultades que se ejercitan a través de los mismos. Lo que sí puede suceder es que tales derechos y potestades quedan afectos mediatamente en cuanto son limitados, modificados o reducidos por la prescripción o caducidad de las facultades que subyacen en los mismos. AGUADO I CUDOLÀ, V.: Prescripción ...op. cit. pág. 25 
tro del cual la Administración puede y debe ejercitar la potestad sancionadora emanando actuaciones dirigidas a calificar la infracción e imponer la sanción tributaria. En su aspecto negativo, significa que, expirado este plazo, la Administración ya no puede sancionar la infracción $\mathrm{y}$, en este sentido, puede decirse que esta prescripción es causa de extinción de la responsabilidad infractora ${ }^{87}$.

\section{III.3.1. Día inicial del cómputo del plazo prescriptivo}

En primer lugar, es preciso concretar cuál es el momento a partir del que comienzan a correr los plazos de prescripción.

El artículo 189.2. ${ }^{\circ}$ de la LGT establece que el plazo de prescripción para imponer sanciones tributarias será de cuatro años y comenzará a contarse "desde el momento en que se cometieron las correspondientes infracciones ${ }^{88} »$, sin que la clandestinidad u ocultación en la infracción sea óbice para el inicio de su prescripción, lo que en la práctica podría conducir a la imprescriptibilidad de las infracciones ${ }^{89}$.

En relación a este último extremo, debemos comentar el artículo 39.2 de la Ley 35/2006, de 28 de noviembre, del Impuesto sobre la Renta de las Personas Físicas y de modificación parcial de las leyes de los Impuestos sobre Sociedades, sóbrela Renta de no Resi-

87 DE MIGUEL CANUTO,E.: La prescripción...op. cit.págs. 15 y 16.

88 LAMOCA PÉREZ critica la reducida regulación frente a la exhaustiva de los artículos 66 a 70 LGT, y así lo podemos ver en la ausencia de normas sobre el inicio del plazo de prescripción, y en la deficiente, por escasa, referida a su interrupción. LAMOCA PÉREZ,C.: Infracciones...op. cit. pág. 215; El plazo deberá computarse a partir del día que la actividad del particular se haya realizado. Ahora bien, tal actividad ha de constituir el presupuesto suficiente para que pueda ejercitarse la potestad administrativa de que se trata. AGUADO I CUDOLÀ, V.: Prescripción...op. cit. pág. 36; Y ello con independencia de que los efectos de la infracción se manifiesten o no de manera periódica. STSJ Aragón de 27 de febrero de 2001; En el ámbito penal, frente al sistema vigente, en el que el dies a quo - en general - se computa desde el momento de su comisión-, RAGUÉS estima que el modelo que se decanta por el día de trascendencia pública es una opción a tener en cuenta, aunque no parece aportar muchas ventajas si se lo compara con el sistema vigente. Con todo, no debe descartarse la conveniencia de esta posibilidad si en un determinado sector de delincuencia se detecta un número excesivamente elevado de impunidades por prescripción, que pueda afectar negativamente al correcto cumplimiento de la función del sistema penal. En tales casos nada se opone a que se establezca algún tipo de regla ad a.C. que retrase el inicio del cómputo de los plazos hasta el momento de conocimiento (o conocimiento potencial) de la víctima o colectividad...como en el caso de los delitos con víctimas menores de edad. RAGUÉS ...2004,op. cit.págs. 149150.

${ }^{89}$ LOZANO CUTANDA,B.: La extinción ...op. cit.págs. 212-213. 
dentes y sobre el Patrimonio, y el artículo 121.6, de la vigente Ley 27/2014, de 27 de noviembre, del impuesto sobre sociedades -anterior art. 134.6 del Real Decreto Legislativo 4/2004, de 5 de marzo por el que se aprueba el Texto Refundido de la Ley del impuesto sobre sociedades-, ambas normas, en su versión modificada por la Ley 7/2012, de 29 de octubre, de modificación de la normativa tributaria y presupuestaria y de adecuación de la normativa financiera para la intensificación de las actuaciones en la prevención y lucha contra el fraude - de la que destacamos también su Disposición adicional primera ${ }^{90}$ y, especialmente, segunda-, así como la Disposición adicional decimoctava de la Ley General Tributaria. Todos estos preceptos han resultado duramente criticados tanto por la doctrina tributarista ${ }^{91}$ como por la Comisión europea —a través de su Dictamen

90 El resultado final no es sino el de establecer tres sanciones distintas a un mismo infractor por una misma conducta, lo que supone la flagrante vulneración del principio de non bis in idem. BADÁS CEREZO, J. y MARCO SANJUÁN, J. A.: Prevención del Fraude y Amnistía Fiscal , Lex Nova Thomson Reuters, Valladolid, 2012, pág. 207; De modo matizado ORENA a nuestro modo de ver, cabría plantearse la vulneración del principio del non bis in idem únicamente en relación a la primera y tercera de las sanciones que se han mencionado, en cuanto que la imputación en el IRPF o en el IS, si bien no es sino la consecuencia de no haber cumplido con la obligación de informar de bienes o derechos situados en el extranjero, no es propiamente una sancióncon lo que se podría plantear que siendo el incumplimiento de la obligación formal el medio necesario para que se sancione con la multa adicional del $150 \%$, nos encontraríamos ante una vulneración del non bis in idem ya que se estarían sancionando por un lado el incumplimiento de la obligación formal, y por otro la consecuencia de dicho incumplimiento. ORENA DOMINGUEZ, A.: Medidas de lucha contra el fraude fiscal, Revista Quincena Fiscal, Cizur Menor, núm.3/2014, BIB 2014\432

91 SIMÓN ACOSTA, E.: Declaración Se estrecha el cerco al fraude fiscal internacional, Actualidad Jurídica Aranzadi, Cizur Menor, núm. 883/2014; SIMÓN ACOSTA, E.: Declaración de bienes en el extranjero: un piélago de irracionalidad e inconstitucionalidad, Actualidad Jurídica Aranzadi, Aranzadi, Cizur Menor, núm. 898/2015, BIB 2015/214; De manera crítica, cuando la ley habilita al Gobierno para su desarrollo, como hace la disposición adicional $18 .^{\text {a }}$ LGT, no cabe un cumplimiento puramente formal de esa habilitación, traspasando la competencia al Ministro, y menos aun puede entenderse implícita una subdelegación de este tipo. Cuestión distinta es que el Decreto no agote el desarrollo de la ley en algún punto concreto y confíe al Ministro una regulación más detallada, que es a lo que se refiere el art. 7.1 LGT en su primera parte. Y es lo que hace el Decreto al remitir la aprobación del Modelo a una Orden ministerial. Pero el establecimiento de supuestos de presentación telemática obligatoria va mucho más allá de la aprobación del modelo. En resumen, los arts. 42 bis, 42 ter y 54 bis (RD 1065/2007) únicamente habilitan a la Orden para aprobar el modelo, pero no para establecer los supuestos en que es necesaria la presentación telemática y, menos aún, para generalizar la obligación de usar medios telemáticos. Tendría que haber sido el Decreto, y no la Orden, el que impusiera la obligación de presentación telemática. E incluso es discutible que el Decreto pudiera hacerlo sin una previa habilitación por ley. Pero desde luego la Orden no tiene rango suficiente...En el caso que nos ocupa, en cambio, la obligación de utilizar medios telemáticos está solo en la Or- 
den y no hay base para la misma ni en la Ley ni en un Decreto... En el caso que nos ocupa hay base legal para imponer la obligación de declarar, pero no para imponer una declaración telemática . Y como no hay impresos que permita la declaración en papel, habrá que concluir que la sanción no es exigible por el momento, y que no se puede sancionar a quienes no hayan presentado la declaración antes del pasado 30 de abril. FALCÓN Y TELLA, R.: El modelo 720 (y II): ¿es una obligación, son tres, o se trata de una obligación inexigible hasta que se apruebe un modelo para la presentación en papel? Revista Quincena Fiscal, Cizur Menor, núm.12/2013, BIB 2013\1286; CALVO VÉRGEZ, J.: La aplicación de la orden HAP/72/2013, de 30 de enero, por la que se aprueba el modelo 720, declaración informativa sobre bienes y derechos situados en el extranjero. Principales cuestiones conflictivas, Revista Quincena Fiscal, Cizur Menor, núm.17/2014, BIB 2014\3379; Esta ha sido considerada como un "auténtico disparate que más pronto o más tarde habrá que eliminar o reducir radicalmente», y ello con independencia de que resulte importante tener información sobre el dinero y los bienes situados en el exterior, pero sin que ese legítimo fin justifique la imposición de una obligación tan amplia. Es criticable su ubicación, ya que se regula de una forma aislada, lo que siguiendo principios generales esenciales, debería ser objeto de una regulación sistemática. Máxime cuando se refiere a un nuevo deber de informar, muy cerca de la naturaleza de las demás obligaciones de información. Se debe esperar al desarrollo reglamentario para ver qué se entiende con precisión por «dato o conjunto de datos», tarea que sería propia de la Ley para respetar el principio de legalidad sancionadora... Desde el momento en que se establece que las leyes reguladoras de cada tributo podrán establecer consecuencias específicas para el caso de incumplimiento de esta obligación de información, se podría estar vulnerando el principio de non bis in idem. Principio que puede resultar malherido porque ya existen otras normas del ordenamiento jurídico que contemplan estas conductas y llevan aparejadas las correspondientes sanciones, como pueden ser la Ley 19/2003, de 4 de julio, sobre régimen jurídico de los movimientos de capitales y de las transacciones económicas con el exterior, o el Real Decreto 1816/1991, de 20 de diciembre, sobre transacciones económicas con el exterior, que también regula similar falta de información. ORENA DOMÍNGUEZ, A.: Medidas de lucha ...op. cit.; Pero es que además infringe el principio de proporcionalidad que debe presidir toda medida, en cuanto que incumple con tres requisitos tal y como establece la STC 207/1996, de 16 de diciembre 30: "En este sentido, hemos destacado ( SSTC 66/1995 y 55/1996 ) que, para comprobar si una medida restrictiva de un derecho fundamental supera el juicio de proporcionalidad, es necesario constatar si cumple los tres siguientes requisitos o condiciones: «si tal medida es susceptible de conseguir el objetivo propuesto (juicio de idoneidad) ; si, además, es necesaria, en el sentido de que no exista otra medida más moderada para la consecución de tal propósito con igual eficacia (juicio de necesidad) ; y, finalmente, si la misma es ponderada o equilibrada, por derivarse de ella más beneficios o ventajas para el interés general que perjuicios sobre otros bienes o valores en conflicto (juicio de proporcionalidad en sentido estricto) ", así como jurisprudencia del Tribunal de Justicia de la Unión Europea ...La obligación de información sobre bienes y derechos situados en el extranjero, que está recogida en la Disposición Adicional Decimoctava de la Ley 58/2003, General Tributaria, y que tiene como precedente a la Foreign Account Tax Compliance Act (FATCA), aprobada el 18 de marzo de 2010 por Estados Unidos... la Disposición Adicional Decimoctava establece la obligación de informar sobre cuentas, títulos, activos, valores o derechos representativos, bienes inmuebles y derechos sobre los mismos, siempre que se encuentren en el extranjero. ¿Y por qué no el oro, los barcos, las cajas fuertes? Ello pone de manifiesto que el diseño del modelo 720 es totalmente caprichoso, al servicio de la comodidad administrativa, lo que resulta incompatible con el princi- 
motivado de infracción número 2014/4330, de fecha 15 de febrero de 2017, en relación con la obligación de información respecto de los bienes y derechos situados en el extranjero ( $\left(\text { Modelo } 720 »^{92}\right)^{93}$ Si no existe obligación de declarar, la presentación de modelo 720 , incluso, puede dar lugar a la comisión de una infracción tributaria (DGT CV 20.5.2015; CV 31.3.2016).

pio de proporcionalidad y con la interdicción de la arbitrariedad... las sanciones resultan desproporcionadas ya que no están en función del valor de los bienes omitidos en la declaración, lo que va en contra de toda lógica en cuanto que se trata de una declaración informativa que tiene por objeto datos valuables. Por ejemplo, si se deja de declarar una cuenta con 10 millones la sanción será de 10.000 euros, mientras que se si no se declara una cuenta con 50.000 euros y un fondo de inversión con 50.000 euros, la sanción será de 20.000 euros, lo que resulta desproporcionado y arbitrario. FALCÓN Y TELLA, R.: «La obligación de informar sobre bienes y derechos situados en el extranjero", AEDAF, Revista Interactiva Actualidad, n. ${ }^{\circ}$ 29/2013; (Se achaca la)deficiente técnica legislativa que se ha utilizado, en cuanto que hubiera sido más lógico incardinar esta nueva obligación de información en el art. 93 LGT. PEDREIRA MENÉNDEZ, J.: «La obligación de información sobre bienes y derechos situados en el extranjero", Quincena Fiscal Aranzadi, Cizur Menor, núm. 4/2013; Introduce un peor trato en que quedan los bienes pertenecientes a contribuyentes españoles ubicados en el extranjero, respecto a los bienes ocultos situados en territorio español, discriminación que resulta injustificada. BADÁS CEREZO, J. y MARCO SANJUÁN, J. A.: Prevención del Fraude ...op. cit.; Las sanciones son desproporcionadas en relación a una obligación que pone de manifiesto el fracaso de los distintos mecanismos de intercambio de información tributaria entre los Estados. GARCÍA NOVOA, C.: «Infracciones y sanciones», en Comentarios a la Ley de Lucha contra el Fraude Fiscal, Aranzadi, 2013, págs. 28 y ss.; no existe la proporcionalidad entre el desvalor del comportamiento tipificado y la cuantía de la sanción que exige el TC, en otras en la STC 161/1997. PEDREIRA MENÉNDEZ, J.: «La obligación de información sobre bienes y derechos situados en el extranjero", Quincena Fiscal Aranzadi, Cizur Menor, núm. 4/2013; SÁNCHEZ PEDROCHE, J. A.: «Primeras y preocupantes impresiones sobre el anteproyecto de ley de modificación de la normativa tributaria y presupuestaria para la lucha contra el fraude», Quincena Fiscal Aranzadi, Cizur Menor, núm 11/2012 , pág. 10;SÁENZ DE OLAZAGOITIA DÍAZ DE CERIO, J.: «Regularización fiscal (con o sin "amnistía» y ganancias no justificadas de patrimonio)», Quincena Fiscal Aranzadi, Cizur Menor, núm. 17/2012 , pág. 3.

${ }_{92}$ Según la SAN, Sección 7. a, de 24 febrero 2014 la Declaración informativa sobre bienes y derechos situados en el extranjero (disp. adic. 18. ${ }^{a}$ LGT/2003) aprobada en la Orden HAP /72/2013, de 30 enero, por la que se aprueba el modelo 720, de declaración informativa sobre bienes y derechos situados en el extranjero, trata obligaciones de información ya previstas en la norma con rango de ley, y no establece restricciones del derecho a la libre circulación de capitales.

${ }_{93}$ Existe presentada una reclamación ante el Defensor del Pueblo Europeo, denunciando que resulta inexplicable que, ante una vulneración tan flagrante del Derecho UE, la CE no haya tomado la decisión de llevar el Modelo 720 ante el Tribunal de Justicia de la UE, que el expediente lleva un retraso que excede de lo razonable y que infringe el principio de buena administración. Tal reclamación está admitida a trámite por el Defensor del Pueblo Europeo el 27/11/2018 con n. ${ }^{\circ} 1854 / 2018 /$ SRS. 
Frente al reiterado criterio ${ }^{94}$ que mantenía los incrementos (descubiertos) no justificados de patrimonio como presunción iuris tantum, con la Ley 7/2012 se transforma ${ }^{95}$ en una presunción iuris et de iure ${ }^{96}$, aunque se matice por algún sector doctrinal ${ }^{97}$, de modo que, de manera clara el contribuyente no podrá probar la titularidad de los bienes situados en el extranjero desde una fecha anterior al periodo de prescripción como consecuencia del incumplimiento del deber de informar, lo cual lleva a la imprescriptibilidad de tales ganancias patrimoniales ${ }^{98}$, si bien no se considerará ganancia patrimonial no justificada cuando se acredite que la titularidad de los bienes o derechos se

${ }_{94}$ Tanto el propio Tribunal Supremo (STS 29.3.1996) como el Tribunal Económico-Administrativo Central (RTEAC 10.7.2008) califican los incrementos no justificados de patrimonio de presunción iuris tantum imputables al último período no prescrito la tenencia de bienes y derechos que no se corresponden con renta y patrimonio declarados, debiendo ser el contribuyente quien deba acreditar un origen distinto al de la presunción legal. La presunción se compone, a su vez, de dos presunciones, la primera sobre la obtención de renta con la que se adquiere el patrimonio descubierto y la segunda referida al momento en que se entiende adquirida dicha renta y que coincide con el ejercicio en que se descubre el patrimonio.

95 Es decir, las rentas que se descubran, materializadas en bienes y derechos que no hayan sido declarados en la nueva declaración informativa, se imputarán siempre al último período impositivo de entre los no prescritos, independientemente de cuál sea la fecha de su adquisición, por lo que el contribuyente no podrá probar su prescripción. MARTÍNEZ-CARRASCO PIGNATELLI, J. M.: «Análisis de las reformas introducidas por la Ley 7/2012, de prevención y lucha contra el fraude fiscal», Quincena Fiscal Aranzadi, Cizur Menor, núm. 1/2013 .

96 Así, mientras que en el párrafo primero del art. 39 se establece una presunción iuris tantum de rentas ocultas asociada a bienes o derechos no declarados, que siempre se ha podido destruir demostrando que los bienes ya eran propiedad del contribuyente en un período prescrito43, en el párrafo segundo se establece una presunción iuris et de iure que no permite la prueba de que los bienes o derechos no declarados en el extranjero se poseían desde ejercicios prescritos, lo que resulta descabellado. ORENA DOMÍNGUEZ, A.: Medidas...op. cit.

97 La novedad introducida por el nuevo párrafo del artículo 39 radica en que aquella presunción iuris tantum se transforma en una presunción a mitad de camino entre ésta y la presunción iuris et de iure cuando el contribuyente incumpla la obligación de información de la Disposición adicional decimoctava. Incluso, nos atreveríamos a afirmar que, de facto, se convierte en presunción iure et de iure, cuando se incumpla la obligación de informar, como se expone a continuación. BERTRÁN GIRÓN, M. ${ }^{\mathrm{a}}$. Y GARCÍA CARACUEL, M. ${ }^{\mathrm{a}}$. : «El establecimiento de la obligación de información sobre bienes y valores en el extranjero vinculada a la imputación de ganancias patrimoniales no justificadas en el Impuesto sobre la Renta de las Personas Físicas», Crónica Tributaria, núm. 4, 2013, pág. 7.

98 Pese a que la normativa solo contempla un criterio de imputación temporal, en la práctica supone la imprescriptibilidad de estas rentas en los impuestos sobre la renta y sociedades. Y ello ya que, frente a dicha presunción de renta, no cabe aportar, como prueba en contrario, la titularidad de los bienes desde un ejercicio prescrito. Tan solo cabe demostrar, para desvirtuar la presunción, que los bienes se corresponden con renta declarada. 
corresponde con rentas declaradas ${ }^{99}$, o bien con rentas obtenidas en periodos impositivos en los que no se tuviese la condición de contribuyente de IRPF (esto es, que no fuera residente). Sólo si se justifica que ha sido titular por alguna de estas dos razones, en un periodo ya prescrito, no se integrará ${ }^{100}$. Sin embargo, si no pueden acreditarse tales datos, se imputará sin tener en cuenta los plazos de prescripción ${ }^{101}$, siempre y cuando se incumpla la obligación de informar antes referida. Se presume, entonces, que se han adquirido con dinero de origen dudoso y por eso no se puede justificar y no resultan aplicables los plazos de prescripción, lo que infringe la capacidad contributiva, puesto que supone gravar una renta ficticia, o pretérita, y el principio de capacidad exige gravar una renta actual ${ }^{102}$.

${ }^{99}$ El hecho de que estos bienes o derechos hayan sido adquiridos en períodos ya prescritos supone una difícil prueba de acreditar las rentas por medio de las cuales se han generado. BADÁS CEREZO, J. y MARCO SANJUÁN, J. A.: Prevención del Fraude ,op. cit.

100 Además, ni siquiera se excluyen los casos en los que no ha existido defraudación o elusión del impuesto, por ejemplo cuando los bienes radicados en el extranjeros se hubiese obtenido a través de operaciones exentas o no sujetas en España, ya que la norma sólo permite enervar la presunción acreditando la adquisición con rentas declaradas o en un ejercicio en que no fuera contribuyente por el impuesto (por ejemplo porque fuera no residente). FALCÓN Y TELLA, R.: "La obligación de informar...op. cit.; En lo que al principio de capacidad económica se refiere, podría plantearse si se vulnera este principio constitucional, ya que no se sujeta a tributación la capacidad económica actual sino la renta obtenida en los periodos anteriores y que supuso la adquisición del patrimonio objeto de regularización. Incluso podría darse el supuesto de que el contribuyente no tenga los bienes en el momento de una comprobación tributaria.

En cuanto al principio de no confiscatoriedad, es importante señalar que, en caso de calificarse el patrimonio como ganancia no justificada e imponerse la sanción del $150 \%$, el resultado económico sería claramente confiscatorio. FAYOS, C.: Modelo 720: el fin no justifica los medios, Actualidad Jurídica Aranzadi, Cizur Menor, núm.911/2015.

${ }^{101}$ Habría que distinguir dos hipótesis, la primera correspondiente a aquellos supuestos en los que los elementos imponibles se habrían ocultado y las autoridades no dispusieran de indicio alguno para iniciar una investigación, y la segunda relativa a aquellos supuestos en los que las autoridades tributarias sí dispusieran de información relativa a dichos elementos imponibles. Para los supuestos correspondientes a la primera hipótesis sí sería posible ampliar el plazo de prescripción -y decimos ampliar, no la imprescriptibilidad-. Respecto a los supuestos relativos a la segunda hipótesis, sólo estaría justificada la ampliación del plazo de prescripción en el tiempo necesario para solicitar la asistencia mutua del Estado en cuestión, cosa que en el caso español no es necesario, pues la notificación del inicio del procedimiento de asistencia mutua provoca ya la interrupción de la prescripción. FALCÓN Y TELLA, R.: «La obligación de informar...op. cit.

${ }^{102}$ FALCÓN Y TELLA, R.: «La obligación de informar ...»; Al integrar las ganancias en el período impositivo más antiguo entre los no prescritos, se olvida el período real de generación de la renta, en contra de todos los principios que rigen la imposición del tributo. Lo que se obtiene con ello es una sanción encubierta al exigirse intereses de demora por la cuota no ingresada durante más días, aunque dicha renta no existiera en el ejercicio al que se pretende su imputación. PEDREIRA MENÉNDEZ, J.: «La obligación de información ...». 
Así las cosas, y siguiendo el razonamiento de la Comisión europea $^{103}$, si bien el Tribunal de Justicia de la Unión Europea aceptón ${ }^{104}$ que una norma según la cual «se aplica un plazo más largo en el caso de los bienes poseídos en otro Estado miembro», no puede deducirse de dicha afirmación la aceptación de la inexistencia de prescripción. Un "plazo más largo" no puede interpretarse en el sentido de la inexistencia de dicho plazo, o en el sentido de un plazo suficientemente largo como para atenuar las consecuencias del paso del tiempo.

Asi las cosas, por lo que respecta a los supuestos en los que no se aplica prescripción alguna, como el genocidio y otros delitos penales similares, o el terrorismo, se trata de hechos jurídicos que implican las formas más graves de violación de los derechos humanos, que no se dan en los casos de fraude, elusión o evasión fiscales, y en el caso de la imprescriptibilidad en materia de relaciones paterno-filiales, los expertos aluden al contenido vital de dichas relaciones, que no puede encontrarse en las relaciones entre la Administración tributaria y los contribuyentes, aunque cabe añadir que la deuda concreta en concepto de pensiones alimenticias de los progenitores sí que prescribe, tal como se contempla en el artículo 1966 del Código Civil español.

Frente a lo anterior, recordemos, no cabrá oponer que el único medio que tiene el Estado español de disponer de información sobre los mismos sea la información facilitada por el contribuyente mediante la presentación del Modelo $720^{105}$, pues existen medios menos

${ }^{103}$ Recordemos que En definitiva, la Comisión no cuestiona que España pueda exigir la presentación del modelo 720 , por mucho que este, por sí mismo, implique cierta restricción de las libertades antes mencionadas. Lo que cuestiona, con fundamento, es la proporcionalidad de las medidas asociadas a su falta de presentación, o presentación extemporánea o defectuosa. Ahora bien, la decisión de la Comisión carece, en principio, de efecto jurídico directo. En su caso, determinará que se someta el asunto al conocimiento del Tribunal de Justicia de la Unión Europea. Por ello, entendemos que son dos las medidas que deberían introducirse a tal fin. En primer lugar, sustituir la imprescriptibilidad de la ganancia patrimonial no justificada por un plazo de prescripción más largo que el general de cuatro años previsto en la Ley General Tributaria. Dicha posibilidad ha sido expresamente aceptada por el tribunal. En segundo lugar, acomodar las consecuencias de la no presentación puntual, completa y correcta al régimen general de aquella ley.

${ }_{104}$ Véase el asunto C-157/08, Passenheim-vfm Schoot, apartado 86.

105 La Comisión Europea opina que existen medios suficientes para obtener información sobre los bienes poseídos en el extranjero a fin de liquidar los impuestos correspondientes. El intercambio automático de información establecido en las Directivas sobre cooperación administrativa21 en vigor abarca la información relativa a los intereses percibidos por los particulares procedentes de las cuentas bancarias y otros valores, los productos de seguro de vida y los bienes inmuebles, Bien es verdad que esta vía de cooperación administrativa no da cabida a otros tipos de bienes a que se refiere el Modelo 720, principalmente las cuentas bancarias y los valores mantenidos por entidades y las acciones. No obstante» las Administraciones tribu- 
restrictivos ${ }^{106}$ que el establecimiento de una presunción iuris et de iure, y siguiendo a la jurisprudencia sobre presunciones, aun siendo aceptándolas, con ciertos restricciones en materia de procedimientos de aplicación de los tributos, en modo alguno resultan posible en materia sancionadora (SsAN, Sección 2. ${ }^{\mathrm{a}}, 18.10 .2012$ y 13.12.2012).

Por lo anterior, debemos sostener que, pese al loable propósito legislativo que pretende evitar la prescripción relativa a bienes

tarias pueden asimismo recurrir al intercambio de información previa solicitud, Estas solicitudes pueden referirse a bienes vinculados a los intereses percibidos por los contribuyentes y notificados a través de los instrumentos de intercambio automático de información. Pueden referirse asimismo a toda información que resulte pertinente a efectos de la percepción del impuesto, incluida la relativa a los activos financieros que poseen los bancos y las acciones. En el marco de las auditorías e inspecciones se hace uso de muy diversas técnicas de investigación y se dispone de otros recursos para identificar los bienes de origen extranjero, tales como la contabilidad de los contribuyentes, sus transferencias bancarias y las disposiciones financieras sobre el control de las operaciones extranjeras o en divisas. Además, y en el curso de dichos procedimientos, las Administraciones tributarias pueden obtener pruebas de las inversiones en el extranjero» como por ejemplo el pago de impuestos extranjeros o los pagos por servicios prestados en el extranjero, incluidos los gastos por servicios jurídicos, contables1 bancarios o los gastos de viaje que pueden comprobarse mediante tales instrumentos jurídicos. Aceptar lo contrario equivaldría a admitir que» antes de la introducción del Modelo 720, la Administración tributaria española había sido incapaz de liquidar impuestos en aquellos casos en que los contribuyentes mantuvieran bienes en el extranjero y no notificaran la renta correspondiente. Cabe añadir que España implemento la normativa relativa a la transparencia fiscal internacional referida a sociedades extranjeras controladas en 1995. Ello le exige ser capaz de evaluar la renta obtenida por una sociedad no residente cuyas acciones estén en posesión de un contribuyente residente. Se trata de un caso típico de activos poseídos en el extranjero, Sí el legislador español introdujo esta normativa y la ha mantenido en vigor durante más de veinte años, cabría esperar razonablemente que la Administración tributaria española fuera capaz de determinar los impuestos en el caso de los activos poseídos en el extranjero,

Por último, las autoridades españolas alegan que, de no existir la obligación de información relativa a los bienes y derechos poseídos en el extranjero, no quedaría garantizado que dispusieran de los instrumentos necesarios para conocer la existencia de dichos bienes y de la renta derivada de los mismos que es preciso declarar. Es decir, que si el contribuyente no cumpliera con la obligación de información que le impone el Modelo 720, las autoridades españolas carecerían de información sobre los bienes y derechos poseídos en el extranjero y no serían capaces de liquidar los impuestos correspondientes. De ser cierto este extremo, al contribuyente le resultaría mucho más fácil simplemente eludir las obligaciones impuestas por el Modelo, dado que las autoridades fiscales no sabrían que posee bienes en el extranjero. Así, se llegaría a la conclusión de que las obligaciones impuestas a través del Modelo serían totalmente ineficaces con vistas a comprobar la propiedad real poseída por los contribuyentes en el extranjero, en caso de que dicha propiedad no fuese notificada. En ese caso, nunca se lograría el objetivo legítimo perseguido mediante la introducción de tal obligación.

106 Como los instrumentos de intercambio de información, asistencia mutua y cooperación.

(C) UNED. Revista de Derecho UNED, núm. 24, 2019 
y derechos situados en el extranjero, la medida, analizada desde el prisma del principio de seguridad jurídica regulado en el art. 9.3 CE supone una derogación, de hecho, de la prescripción ${ }^{107}$ por vía de presunción, sin prueba en contrario, atentatoria del fundamento último del instituto de la prescripción colisionando con las normas fundamentales que regulan nuestro ordenamiento jurídico ${ }^{108}$, revocándose, por retroacción de los efectos de una norma posterior, una prescripción, que bien pudiera haberse ya ganado - es decir, con anterioridad al 31.10.2012-, y ello en base al incumplimiento de un

${ }^{107}$ La imprescriptibilidad vulneraría la libre circulación de capitales y la libertad de establecimiento, ya que si bien los apartados 1 y 2 del art. 65 TFUE permiten tratamientos diferenciados al permitir a los Estados miembros a aplicar su Derecho fiscal distinguiendo entre contribuyentes cuya situación difiera con respecto a su lugar de residencia o con respecto a los lugares donde esté invertido su capital, su apartado 3 establece un límite: dichas medidas no podrán constituir ni un medio de discriminación arbitraria ni una restricción encubierta de la libre circulación de capitales y pagos. FALCÓN Y TELLA, R.: «La obligación de informar...op. cit.

108 Incluso a nivel europeo la Comisión Europea considera que la normativa española en la materia -Disposición Adicional Decimoctava Ley 58/2003 (LGT), art. 39 Ley 35/2006 (Ley IRPF), art. 121.6 Ley 27/2014 (Ley IS), y art. 134.6 del derogado RDLeg. 4/2004 (TR Ley IS) y Disposición Adicional Primera Ley 7/2012 (Modificación de la normativa tributaria y presupuestaria y de adecuación de la normativa financiera para la intensificación de las actuaciones en la prevención y lucha contra el fraude) - infringe la libre circulación de personas (art. 21 TFUE), la libre circulación de trabajadores (art. 45 TFUE y art. 28 Acuerdo EEE), la libertad de establecimiento (art. 49 TFUE y art.31 Acuerdo EEE), la libre prestación de servicios (art. 56 TFUE y art. 36 Acuerdo EEE) y la libre circulación de capitales (art. 63 TFUE y art. 40 Acuerdo EEE), en la medida en que establece un régimen de declaración fiscal en el marco del Modelo 720 que parece discriminatorio y desproporcionado a la luz de la jurisprudencia pertinente del Tribunal de Justicia, y, en particular al imponer:

- multas pecuniarias fijas por incumplimiento de las obligaciones de información del Modelo 720 en lo que se refiere a los bienes y derechos poseídos en el extranjero o por la presentación extemporánea de este último superiores a las establecidas en el régimen general para infracciones similares reguladas en la Ley General Tributaria,

- la tributación de las ganancias patrimoniales no justificadas como consecuencia de la falta de información en el Modelo 720 sobre los bienes y derechos poseídos en el extranjero o de la mera presentación extemporánea de la información que figura en el Modelo 720 sobre dichos bienes y derechos, junto con la negación de la prueba de que la propiedad de los activos se mantiene desde un determinado ejercicio fiscal que ha prescrito; $y$

- una multa pecuniaria proporcional sobre las ganancias patrimoniales no justificadas asociadas a los bienes y derechos que no se comuniquen en el Modelo 720.

En ese sentido, la S TSJ Castilla y León de 28 de noviembre de 2018 considera desproporcionada la sanción de 5.800 euros impuesta al contribuyente que, a pesar de haber cumplido con su deber de informar sobre los bienes y derechos en el extranjero, lo hizo de forma extemporánea. 
deber formal de declaración de bienes ${ }^{109}$ y derechos en el extranjero, que, además, lleva a que mute en incumplimiento de una obligación tributaria principal y material, así el de la cuota tributaria a ingresar, con la consiguiente y desproporcionada sanción tributaria.

El momento de la comisión de las infracciones, tal y como se ha expuesto en líneas precedentes, coincide con el de la concurrencia de todos los elementos de la conducta que se tipifica como tal, y precisamente, en ese instante, se produce la consumación del ilícito. El día inicial en el cómputo de la prescripción viene determinado por un hecho extraprocedimental como es la fecha en que se cometió la infracción ${ }^{110}$. Ahora bien, la consumación de la infracción se pone de manifiesto en momentos distintos en función de que la conducta tipificada consista en una acción o en una conducta omisiva y que exija o no la consecución de un resultado ${ }^{111}$. Así las infracciones de acción consisten en una conducta positiva que supone la contravención de una norma prohibitiva, cuyo

${ }^{109}$ La Dirección General de Tributos, ante estas circunstancias, emitió la Consulta V1434-17 de 6/6/2017 señalando que a las personas que presenten fuera de plazo el Modelo 720 imputándose en IRPF el valor de sus bienes en extranjeros (jaunque estén prescritos!) no se les aplicará la sanción del 150\% que clara y expresamente establece la Ley, sino que se les aplicará el régimen de recargos de hasta el $20 \%$ más intereses de demora.

110 DE DIEGO DÍEZ, L.A.....op. cit.pág. 46.

111 MEMENTO PRÁCTICO FRANCIS LEFEVBRE. Inspección de Hacienda 20082009, Francis Lefevbre, Madrid,2008, pág. 325. El manual establece «la prescripción de la acción para imponer sanciones tributarias se regula de forma separada de la prescripción del derecho de la Administración a determinar la deuda tributaria mediante la oportuna liquidación, incluso tratándose de las infracciones causantes del perjuicio económico tipificadas en la LGT. No obstante el plazo de prescripción en ambos casos es el de cuatro años y el inicio del cómputo de dicho plazo coincide, dado que la infracción se considera cometida no cuando se presenta la autoliquidación o declaración incorrecta, sino cuando finaliza el plazo de declaración presentada evitando incurrir en los tipos definidos en la LGT». Sólo en el supuesto de obtención indebida de devoluciones (art. 193 LGT) no se inician en el mismo momento el plazo de prescripción del derecho de la administración a determinar la deuda tributaria y el de su derecho a sancionar la infracción cometida pues, normalmente, no coincide el momento en que se obtiene la devolución con la finalización del plazo voluntario de declaración; Por su parte, DÍEZ OCHOA indica que «la Administración tributaria entiende que en los casos de los artículos 191 a 198 LGT, tanto si se presenta declaración como si ésta no se presenta, la infracción se entiende cometida el último día del período reglamentario de presentación (excepto la infracción tipificada en el art. $193 \mathrm{~L}$. 58/2003, y en el art. 194 LGT si se presenta la autoliquidación fuera del plazo de declaración). En este sentido la Sentencia del TS, de fecha 26 de julio de 1999. En el caso de que el obligado tributario hubiera presentado la declaración o autoliquidación, se entiende cometida igualmente. El último día del plazo reglamentario de presentación de la correspondiente declaración o autoliquidación. En este sentido la Sentencia del TS de fecha 6 de noviembre de 2000 (se consuma en el momento en que expira el plazo legal voluntario para realizar el pago. Antes no cabe hablar de consumación, pues el sujeto aún podría desistir voluntariamente verificando el pago a través de una declaración complementaria. DÍEZ OCHOA, J.M.: Derecho Tributario...op. cit. pág. 249. 
momento de consumación dependerá de la estructura del tipo infractor. Las infracciones de omisiones, se configuran como conductas negativas, que infringen una norma preceptiva, entre las que se incluyen aquellas descritas por la ley con la expresión «retraso», «negativa» o similares, aunque no es la negativa o el retraso en sí mismo considerado lo que comporta la violación de la norma, sino la omisión del acto o de los actos que la norma misma ordena. La omisión sancionable consiste en un voluntario no hacer concreto, constituyendo sus notas esenciales la naturaleza positiva del precepto y radicar el hecho delictivo en el mismo acto voluntario de inacción. Esta categoría integra las infracciones atinentes a la desobediencia o incumplimiento de los ciudadanos de lo que la ley o la autoridad mandan en concretos casos. Las infracciones de omisión se consumarían en el momento en que el sujeto hubiera debido, lo más tarde, realizar la conducta debida, plazo que partirá en el momento en que debió realizarse la acción que del sujeto se espera $^{112}$. Por otra parte, desde el punto de vista del bien jurídico protegido es sabido que algunas infracciones tratan de salvaguardar la lesión efectiva del mismo, mientras que otras se adelantan a ese momento y tratan de evitar su puesta en peligro.

Por este motivo, es conveniente reiterar el significado de los conceptos mencionados, y con apoyo en los mismos será preciso determinar en qué momento se consuma cada una de las infracciones que se tipifican ${ }^{113}$ en la LGT, teniendo en cuenta la distinción que esta norma realiza entre infracciones leves, graves y muy graves.

112 MARTÍN CÁCERES,A.F.:La prescripción ...op. cit.pág. 114.

113 De la lectura del artículo 25 de la Constitución pueden surgir dudas en relación con el alcance del principio de legalidad en materia de sanciones administrativas, por su parte, el Título IX de la LRJ-PAC (hoy Título preliminar LRJSP, en el cual se desarrollan los preceptos constitucionales que regulan la potestad sancionadora de la Administración, incluye, en su artículo 127 LRJPAC (hoy art. 25 LRJSP), este principio. ZORNOZA PÉREZ, J. J.: El sistema de infracciones y sanciones tributarias. Los principios constitucionales del derecho sancionador, Civitas, Madrid,1992, págs. 72 y 73; El principio de legalidad, aunque observado desde un punto de vista formal, se pone de manifiesto en el aforismo «nullum crimen, nulla poena sine lege». En función de este principio, ningún hecho puede ser considerado como delito sin que una Ley lo haya configurado como tal, ni ninguna pena podrá aplicarse si no ha sido previamente establecida por la Ley. La distinción entre principio de legalidad formal y material, supone responder a la pregunta de si ¿debe ser castigado como vulneración del ordenamiento, sólo lo previsto en la Ley o todo comportamiento socialmente dañoso? El artículo 25.1 de la CE indica que «nadie puede ser condenado o sancionado por acciones u omisiones que en el momento de producirse no constituyan delito, falta o infracción administrativa, según la legislación vigente en aquel momento». A la expresión «legislación vigente» utilizada por la Constitución, se le ha dado un diverso significado en el ámbito penal y administrativo... el término «Ley» es un término equívoco, pues puede tener diversas acepciones, así, puede ser utilizado para designar las normas surgidas de la "potestas normandi» del Estado, es decir, las normas de origen estatal decretadas por la organización política 
constituida en forma de Estado, aunque, en un sentido más estricto, puede referirse a un determinado tipo de norma que ocupa un lugar preponderante entre las emanadas del Estado o de las CC AA, en este sentido «Ley» se opone a reglamento, Resulta generalmente admitido que la expresión «legislación vigente» del artículo 25.1 de la $\mathrm{CE}$, tendrá diverso significado al hacer referencia al ordenamiento Penal y al Administrativo. Si bien la identidad sustancial entre el ilícito penal y el administrativo, justifica su regulación unitaria en la Constitución, la intervención represiva que se produce en el ámbito penal tiene mayor intensidad que la producida en el ámbito administrativo, puesto que puede afectar a la libertad o a otros derechos fundamentales, es esta razón la que acredita el uso de elementos legislativos diversos, como la Ley orgánica o la ordinaria. En función de ello, y de la interpretación conjunta del artículo 25 de la CE con los artículos 9.3, 53.1 y 103 de la CE, consideramos que resulta aplicable en el ámbito sancionador administrativo el principio de legalidad, aunque manifestándose en este ámbito con menor intensidad... administrativo. La cuestión de la intensidad con que este principio deba ponerse de manifiesto en el ámbito sancionador administrativo, va a plantear diversas cuestiones, así, debe determinarse si es la Ley la que debe regular íntegramente las infracciones y sanciones administrativas, o si ésta podrá establecer principios y criterios en función de los cuales se determinen reglamentariamente; en el primer caso estaríamos ante una reserva absoluta, y en el segundo ante una relativa. La gran mayoría de la doctrina va a posicionarse a favor de la segunda de las opciones, aunque defendiendo la necesidad de que la Ley realice una descripción genérica de las conductas sancionables, sin que la remisión a normas reglamentarias suponga una deslegalización de la materia. Sobre este tema señala el TC que resulta necesario que la potestad sancionadora de la Administración se encuentre otorgada mediante norma con rango de Ley, no excluyendo esto la posibilidad de que las leyes contengan remisiones a normas reglamentarias, aunque será necesario que en las primeras se contengan los elementos esenciales de las conductas antijurídicas, la naturaleza y límites de las sanciones a imponer. El principio de legalidad prohibirá una remisión al Reglamento que haga posible una regulación independiente y no claramente subordinada a la Ley. PARADA distingue entre «el principio de «reserva absoluta de Ley» - que opera en materia penal- y de «cobertura legal» —aplicable a las sanciones administrativas-... en el primer caso, la ley legitimadora ha de cubrir por entero tanto la previsión de la penalidad como la descripción de la conducta ilícita (tipicidad) sin posibilidad de completar esa descripción por un reglamento de aplicación o desarrollo; mientras que el principio de «cobertura legal» de las sanciones administrativas sólo exige cubrir con ley formal una descripción genérica de las conductas sancionables y las clases y cuantía de las sanciones, pero con la posibilidad de remitir a la potestad reglamentaria la descripción pormenorizada de las conductas ilícitas, es decir, la tipicidad». CORDERO GARCÍA,J.A.: «La potestad sancionadora...»,op. cit.págs. 1-7; Llegados a este punto, resulta significativa una polémica existente en la actualidad en Francia, donde los artículos 1729 y 1730 del CGI (Code Général des Impôts) establecen de una forma rígida la cuantía de las sanciones más usuales, ante esta situación parte de la doctrina y diversos planteamientos jurisprudenciales defienden la posibilidad de que las sanciones fijadas legalmente sean consideradas como límites máximos dentro de los cuales pueda imponerse una sanción más reducida. Consideramos que el respeto al principio de legalidad no puede suponer obviar otros como el de proporcionalidad de la sanción, pero la solución al problema francés no debe ser la atribución de una competencia discrecional a la Administración o a los órganos jurisdiccionales, al margen de lo previsto en la Ley.[ Vid. Corte Europea de Derechos del Hombre, Sentencias de 1 de diciembre de 1992 (caso Perrin), de 24 de febrero de 1994 (caso Bendenoun), de 29 de mayo de 1997 (caso Malige), de 10 de febrero de 1983 (caso Lecomte), y de 23 de octubre de 1995 (Caso Schmautzer), entre otras. Consejo de Estado Francés, Sentencias de 5 de abril de 1996 (caso Houdmond), y de 4 de marzo de 1991, Corte de Casación Francesa, Sentencia de 29 de abril de 1997 (Caso Ferreira), Consejo Constitucional, Sentencia de 30 de diciembre de 1997. Tribunal Administrativo de Estrasburgo, Sentencia de 8 de diciembre de 1994 (caso Simon).]

(C) UNED. Revista de Derecho UNED, núm. 24, 2019 
Así pues, dado que el bien jurídico protegido a través de la tipificación de las infracciones tributarias es la recaudación de los ingresos, las infracciones que tratan de proteger la efectiva lesión del mismo, esto es, la defraudación tributaria, se pueden denominar infracciones de lesión mientras que los tipos infractores que pretenden evitar que este bien se ponga en peligro, pueden recibir, lógicamente esta calificación. Además, la conducta puede llevarse a cabo realizando una acción que está prohibida por el ordenamiento o no realizando la que la ley exige. Por último, puede ser suficiente la acción u omisión ${ }^{114}$, sin que sea preciso obtener un resultado - son las infracciones de mera actividad cuando hay acción o las de omisión propia cuando no la hay, esto es, se castiga sólo un no hacer, con independencia del resultado-, o se puede requerir que éste se consiga - denominadas infracciones de resultado en los casos en los que hay acción o infracciones de omisión impropia, cuando no es suficiente con el no hacer sino que a su vez ha de producirse un resultado ${ }^{115}$ -

\section{III.3.2. Día final del cómputo del plazo prescriptivo}

En el ámbito administrativo se señala que si un mes comienza a contarse en determinada fecha, en la misma del mes siguiente comenzará un nuevo mes, o sea, que el último día del plazo es el inmediatamente anterior. De este modo, en los plazos fijados en meses o años, el cómputo de fecha a fecha, significa que el último día del plazo se corresponderá en el mes o año correspondiente con el guarismo o cifra anterior a la del día inicial - a las veinticuatro horas-. Así este cómputo más que «de fecha a fecha» es de «momento a momento», lo que es más beneficioso para el imputado, aunque cierto sector jurisprudencial ${ }^{116} \mathrm{y}$ doctrinal ${ }^{117}$ estimen más oportuno que el plazo de fecha a fecha se extinga al finalizar el día equivalente al inicial, en el mes o año correspondiente. De este modo, si en la prescripción in-

114 MARTÍN QUERALT,J.; LOZANO SERRANO,C.; POVEDA BLANCO,F.: Derecho Tributario, Aranzadi, Navarra,2008, pág. 222.

115 FERREIRO siguiendo a Mir Puig, clasifica las infracciones de resultado (arts. 191 a 193 y 201 LGT) y las de mera actividad (el resto de infracciones de la LGT). A su vez distingue si el tipo requiere lesión o basta su puesta en peligro, y los de esta última naturaleza los subdivide en infracciones de peligro concreto - que requiere una efectiva situación de peligro-, y los de peligro abstracto - que no requieren que en el caso concreto la acción cree un peligro efectivo-. FERREIRO LAPATZA, J.J.: Curso de Derecho ...op. cit. 2006, pág. 560.

116 SsTS 22.09.1994 y 4.05.2004.

117 Por todos, Ibíd...op. cit.pág. 50. 
cide el plazo que comienza a contarse desde la comunicación de alguna actuación, el dies a quo en el cómputo de los plazos por meses o por años es, por imperativo legal (art. 30.4 Ley 39/2015, de 1 de octubre, del Procedimiento Administrativo Común de las Administraciones Públicas - LPACAP-), el siguiente al de la notificación o publicación del acto, y el dies ad quem, según el cómputo civil de plazos de fecha a fecha, en el que el día equivalente al inicial del cómputo forma parte del plazo (así una pacífica línea jurisprudencial p.ej. STS 4.03.1980), en cuyo caso, si bien dies a quo non computatur in termino, hay que entender que la exclusión del día en el que se comunicó el acto no impide que el acto se cumpla en igual fecha del mes o año correspondiente, por que únicamente así comprendería con exactitud el mes o año natural, del que excedería en un día si venciera al agotarse el del mismo número del siguiente al de la notificación ${ }^{118}$.

El día final del cómputo de los cuatros, siguiendo para ello el artículo 30 LPCAP, al fijarse el plazo en años, se computará ${ }^{119}$ a partir del día siguiente hábil a aquel en que tenga lugar la notificación o publicación del acto de que se trate, y si en el mes de vencimiento no hubiera día equivalente a aquel en que comienza el cómputo, se entenderá que el plazo expira el último día del mes. Cuando el último día del plazo sea inhábil, se entenderá prorrogado al primer día hábil siguiente. Los plazos expresados en días se contarán a partir del día siguiente a aquel en que tenga lugar la notificación o publicación del acto de que se trate o desde el siguiente a aquel en que se produzca la estimación o la desestimación por silencio administrativo. Por último, cuando un día fuese hábil en el Municipio o Comunidad Autónoma en que residiese el interesado, e inhábil en la sede del órgano administrativo, o a la inversa, se considerará inhábil en todo caso.

A todo ello, debemos añadir que dicho plazo de cuatro años, puede haberse interrumpido y reiniciado varias veces durante la tramitación del procedimiento de aplicación de los tributos, y también suspendido en el ínterin del procedimiento sancionador tributario, sin perjuicio de los supuestos de interrupción justificada aplicables al plazo máximo para resolver el procedimiento sancionador.

118 STS 21.10.1980. Lo que significa que cuando se opera con meses o años, de fecha a fecha, el día inicial es el siguiente al de la notificación, aunque el último día del plazo coincide con el mismo ordinal de la práctica de aquélla, pero en el mes o año inmediatamente posterior (STS 19.04.2004).

119 Así LINDE PANIAGUA, E.: Fundamentos de Derecho Administrativo. Del Derecho del Poder al Derecho de los ciudadanos, COLEX-Uned,Madrid,2009, pág. 323. 
La cuestión se complicará sobremanera cuando se trata de la posible prescripción del incumplimiento de las obligaciones formales que se exijan a terceras personas a las que se refieren los apartados 2 y 3 del art. 70 LGT, cuestión que no encuentra sencilla respuesta en el apartado $3 .^{\circ}$ del precepto en aquellos casos de requerimiento del deber de prestar información tributaria, pues no será fácil conocer si ya ha transcurrido o no el plazo de prescripción de la obligación principal, que puede incluso haberse interrumpido y no ser conocido dicho dato por el tercero.

\section{CONCLUSIONES}

La prescripción, a diferencia del Derecho Civil, sí es una forma - entre otras - de extinción, de la obligación tributaria, de la responsabilidad derivada de la infracción y de la sanción tributaria.

La prescripción de la infracción tributaria es aquel instituto — distinto del de la caducidad- que, sin admitir la validez de lo actuado ilícitamente, y fundado en el principio de la seguridad jurídica, extingue la responsabilidad derivada de la comisión de un ilícito tributario, como consecuencia del paso de un tiempo determinado legalmente y la falta de actividad administrativa eficaz dentro de ese término, imposibilitando la posterior actuación de la Administración Tributaria en orden a sancionar, esto es, impidiendo que la Administración competente ejercite su potestad sancionadora tributaria.

La prescripción tiene su fundamento y razón de ser en la salvaguarda de la seguridad jurídica del ciudadano y en la eficacia del actuar de la Administración, que nos lleva a afirmar la innecesariedad de imponer la sanción transcurrido cierto período de tiempo, instituto que se ubica en el estrato punitivo de la infracción.

Pese a lo dispuesto en la LGT, constitucionalmente no resulta exigible reserva de ley para la determinación de los plazos de prescripción.

Reconocemos la naturaleza material de este instituto, al que no consideramos un simple obstáculo procesal, tiene naturaleza sustantiva y no meramente procedimental, por lo que no será necesaria su alegación por las partes al ser aplicable de oficio.

Lo que en puridad prescribe no es la acción para imponer sanciones sino la exigencia de la responsabilidad que se deriva de la comisión del ilícito tributario. 
Para que prescriba la responsabilidad dimanante de la infracción tributaria se requiere:

1. La consumación de la infracción — cuyo plazo comienza desde que se cometió la infracción (dies a quo) - que se produce cuando se lesiona o se pone en peligro el bien jurídico protegido, debiendo de estarse a la concreta estructura del tipo infractor. A ese efecto habrá que tomar en consideración el diferente plazo de prescripción que la responsabilidad derivada de una conducta adopta, en función que la misma sea calificada como infracción autónoma o como circunstancia de calificación (agravante) de la infracción.

2. También se exige la inactividad — que no pasividad o abandono- o actividad administrativa ineficaz del titular del «ius puniendi», en este caso, de la Administración Tributaria.

3. Que dicha inactividad o actividad ineficaz acontezca durante un período ininterrumpido de cuatro años (dies ad quem). 